\author{
RAFAŁ ROSÓŁ \\ Uniwersytet im. Adama Mickiewicza w Poznaniu \\ ORCID: 0000-0001-7179-7756 \\ e-mail: rafros@amu.edu.pl
}

\title{
EPIGRAFIKA ŁACIŃSKA W FARZE POZNAŃSKIEJ. INSKRYPCJE W OŁTARZACH I KAPLICACH ŚWIĘTYCH JEZUICKICH
}

\begin{abstract}
ABSTRAKT. Rosół Rafał, Epigrafika łacińska w farze poznańskiej. Inskrypcje w ołtarzach i kaplicach świętych jezuickich (Latin Epigraphy in the Parish Church in Poznań. Inscriptions in the altars and chapels of the Jesuit Saints).
\end{abstract}

The paper deals with some Latin inscriptions from the Parish Church in Poznan (the former Jesuit Church). The material under consideration is located in two altars and five chapels devoted to the Jesuit Saints. The author provides a critical edition of the texts, their Polish translations, as well as a commentary.

Keywords: Latin epigraphy; Latin inscriptions; Parish Church in Poznań; Jesuits in Poznań; Jesuit Saints; Saint Stanislaus Kostka; Saint Ignatius of Loyola; Saint Francis Borgia; Saint Aloysius de Gonzaga; Saint John Francis Regis; the Saint Jesuit Martyrs; Saint Francis Xavier.

Obecna fara poznańska, czyli oficjalnie Bazylika kolegiacka pw. Matki Bożej Nieustającej Pomocy, św. Marii Magdaleny i św. Stanisława Biskupa, należała przez blisko siedem pierwszych dekad swojego istnienia - począwszy od konsekracji w 1705 r. - do Towarzystwa Jezusowego. Choć od 1773 r. jezuici nie są już związani z tym kościołem, można by jednak odnieść wrażenie, że nigdy go nie opuścili, ponieważ jego wystrój od czasu decyzji papieża Klemensa XIV w sprawie kasaty zakonu zmienił się jedynie nieznacznie. Dotyczy to również inskrypcji łacińskich, które nie tylko współtworzą barokowy przepych, lecz także - razem z freskami, obrazami i rzeźbami - stanowią nader interesującą realizację programu artystyczno-religijnego Towarzystwa. W ramach niniejszego artykułu zostaną omówione napisy, które występują w poświęconych świętym jezuickim kaplicach i dwóch ołtarzach w ramionach transeptu. Powstały one już po konsekracji kościoła w trakcie prac wykończeniowych trwających do lat 50. XVIII w.

W nawach bocznych stworzono w sumie dziesięć kaplic. Licząc od drzwi wejściowych w kierunku ołtarza głównego są to kolejno kaplice: św. Franciszka Borgiasza, św. Alojzego, św. Michała, św. Józefa i Matki Boskiej w nawie zachodniej (po prawej stronie) oraz św. Jana Franciszka Regisa, św. Rozalii, 
św. Męczenników Jezuickich, św. Franciszka Ksawerego i św. Krzyża w nawie wschodniej (po lewej stronie). Oprócz tego w nawie poprzecznej umieszczono monumentalne ołtarze św. Stanisława Kostki w ramieniu zachodnim i św. Ignacego Loyoli we wschodnim. Jak widzimy, obydwa ołtarze oraz w sumie pięć kaplic dedykowanych jest świętym wywodzącym się z Towarzystwa Jezusowego.

Zaczynając od transeptu, w ołtarzu św. Stanisława Kostki (1550-1568) widnieje jedynie krótka inskrypcja umieszczona w dużym kartuszu u szczytu:

\section{SANCTO | STANISLAO | KOSTKA „Świętemu Stanisławowi Kostce”}

Z kolei w ramieniu wschodnim transeptu znajduje się ołtarz św. Ignacego Loyoli (1491-1556), założyciela i pierwszego generała Towarzystwa Jezusowego. Nad ołtarzem widzimy kartusz - analogiczny do kartusza w ołtarzu św. Stanisława Kostki po przeciwnej stronie - z inskrypcją:

\section{SANCTO | FUNDATORI | IGNATIO ${ }^{2}$ „Świętemu Założycielowi Ignacemu”}

Najważniejszym elementem tego ołtarza jest powstały być może w warsztacie Szymona Czechowicza obraz z lat 50. XVIII w. z przedstawieniem św. Ignacego na zamku Loyola ${ }^{3}$. Na obrazie widoczny jest częściowo rozwinięty dokument leżący na stole z krótkim tekstem (litery odwrócone do góry nogami):

\section{PAULUS P(A)P.(A) III | AD PERPETUAM REI | MEMORI[AM] $]^{4}$ „Papież Paweł III na wieczną rzeczy pamiątkę"}

Ten dokument to wydana przez papieża Pawła III w 1540 r. bulla znana jako Regimini militantis Ecclesiae ( $O$ Kościele walczacym), która zatwierdziła powstanie Towarzystwa Jezusowego. Widniejący na obrazie tekst jest skróconą wersją wstępnej formuły poprzedzającej faktyczny tekst bulli. Formuła ta w oryginalnym dokumencie brzmi następująco: „Paulus episcopus, servus servorum Dei, ad perpetuam rei memoriam”, czyli „Biskup Paweł, sługa sług Bożych,

\footnotetext{
${ }^{1}$ Litery wypukłe, złote na czarnym tle, majuskuła. Wydania: Zwolski 1936: 23; Szczepaniak 1996: 22.

${ }^{2}$ Litery wypukłe, złote na czarnym tle, majuskuła. Wydania: Zwolski 1936: 22; Szczepaniak 1996: 22. SANCTO - Zwolski (1936: 22) zamiast pełnej formy podaje STO w abrewiacji.

${ }^{3}$ O obrazie vide Kurzawa - Kusztelski 1998: 19 i fig. 345.

${ }^{4}$ Litery czarne na białym tle, majuskuła barokowa. Wydania: Zwolski 1936: 22; Szczepaniak 1996: 22. MEMORI[AM] - środkowe litery MORI widoczne są tylko częściowo, natomiast $A M$ są niejako w zwiniętej partii dokumentu.
} 


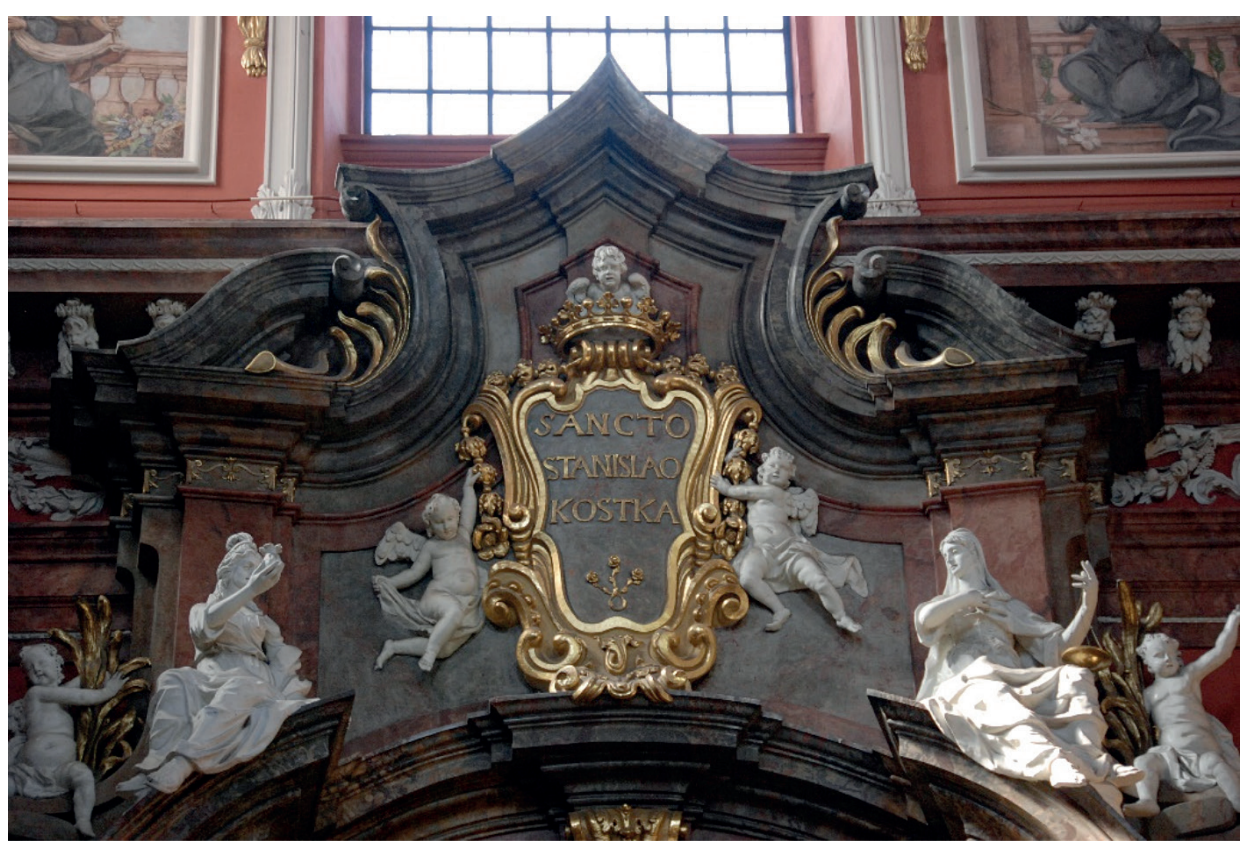

Fot. 1. Kartusz na ołtarzu św. Stanisława Kostki

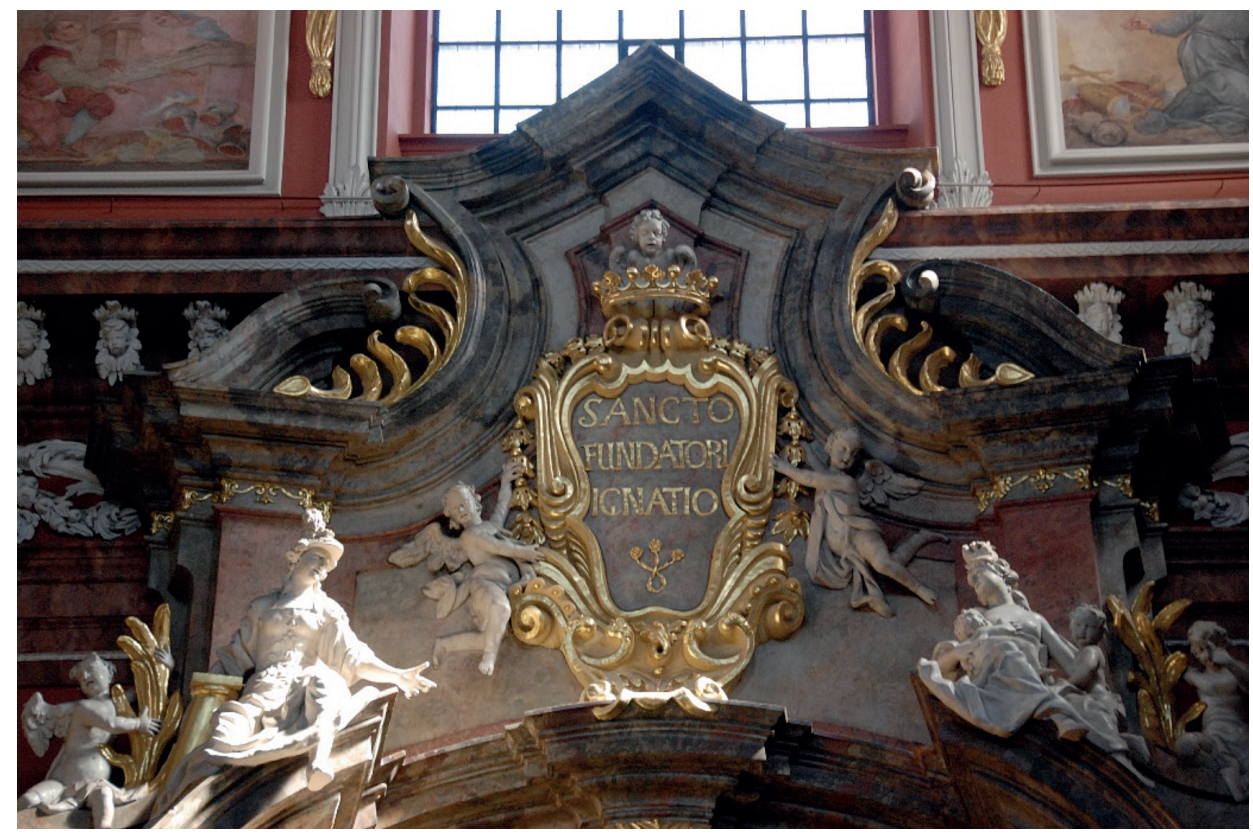

Fot. 2. Kartusz na ołtarzu św. Ignacego Loyoli 


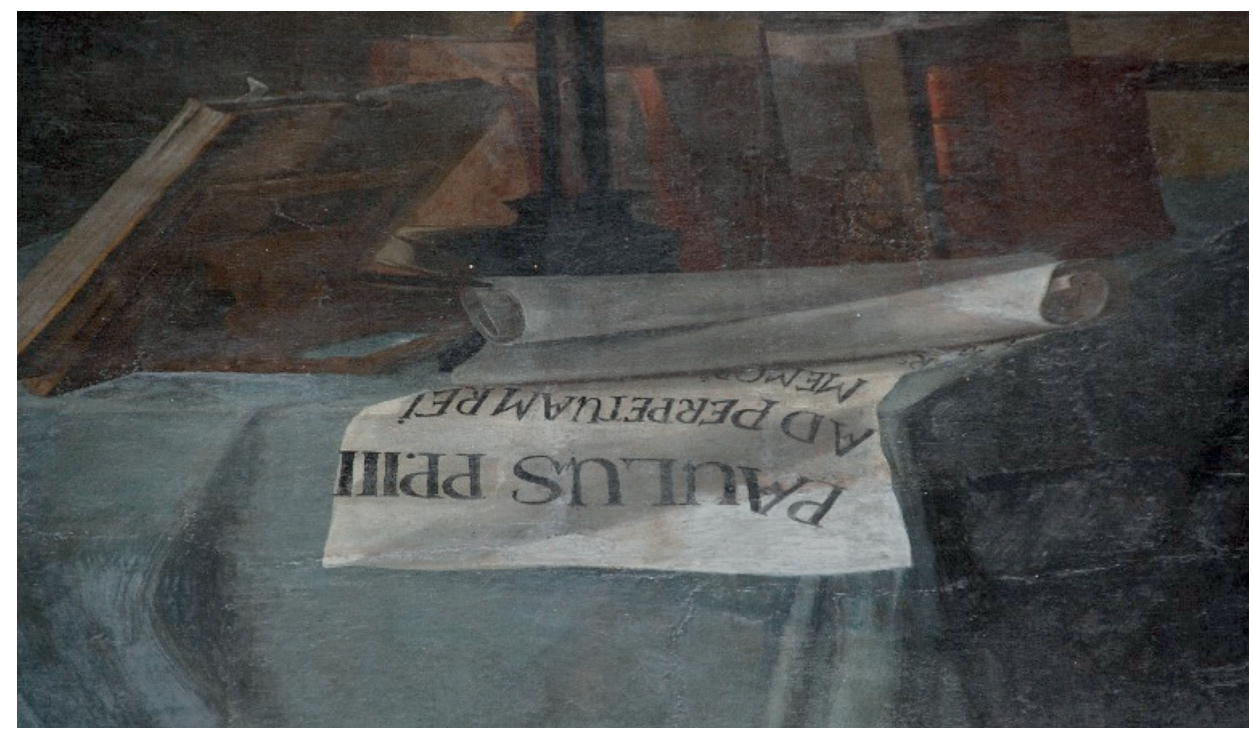

Fot. 3. Szczegół z obrazu w ołtarzu św. Ignacego Loyoli

na wieczną rzeczy pamiątkę"5. Co się tyczy wyrażenia ad perpetuam rei memoriam, było ono stałym elementem bulli papieskich, ale występowało także w innego rodzaju dokumentach. Jako ciekawostkę warto wspomnieć, że obecnie wojewoda wielkopolski przyznaje zasłużonym mieszkańcom województwa brązowy medal pamiątkowy właśnie o nazwie „Ad perpetuam rei memoriam”.

Nawę zachodnią otwiera kaplica św. Franciszka Borgiasza (1510-1572), który pełnił funkcję generała zakonu jezuitów w latach 1565-1572, a zatem w czasie, gdy w Poznaniu powstał klasztor jezuitów wraz z kolegium. W kaplicy tej znajdują się dwie inskrypcje, z których pierwsza widnieje w kartuszu nad ołtarzem:

\section{PRINCI | PUM | MIRACU | $\mathrm{LO}^{7}$ \\ „Cudowi wśród książąt”}

Określenie principum miraculum często było używane w odniesieniu do św. Franciszka Borgiasza, który przed wstąpieniem do zakonu jezuitów był księciem Gandii, miasta położonego na wschodnim wybrzeżu Hiszpanii ${ }^{8}$.

\footnotetext{
${ }^{5}$ Wydanie tekstu bulli w oryginalnym brzmieniu znajduje się w: Sancti Ignatii de Loyola Constitutiones Societatis Jesu, t. I: Monumenta Consitutionum praevia, Roma 1934 (Monumenta Ignatiana ex autographis vel ex antiquioribus exemplis collecta; series tertia), 24-32.

${ }^{6}$ Odznaczenie szczegółowo opisano na stronie Wielkopolskiego Urzędu Wojewódzkiego w Poznaniu: http://www.poznan.uw.gov.pl/ad-perpetuam-rei-memoriam [dostęp: 22.03.2019].

${ }^{7}$ Litery malowane złotą farbą na bordowym tle, majuskuła barokowa. Wydania: Zwolski 1936: 28; Szczepaniak 1996: 30; Owczarzak 2009: 25. Oba wyrazy przeniesione bez oznaczenia.

${ }^{8} \mathrm{Na}$ temat św. Franciszka Borgiasza vide Zaleski 1996: 588-591.
} 


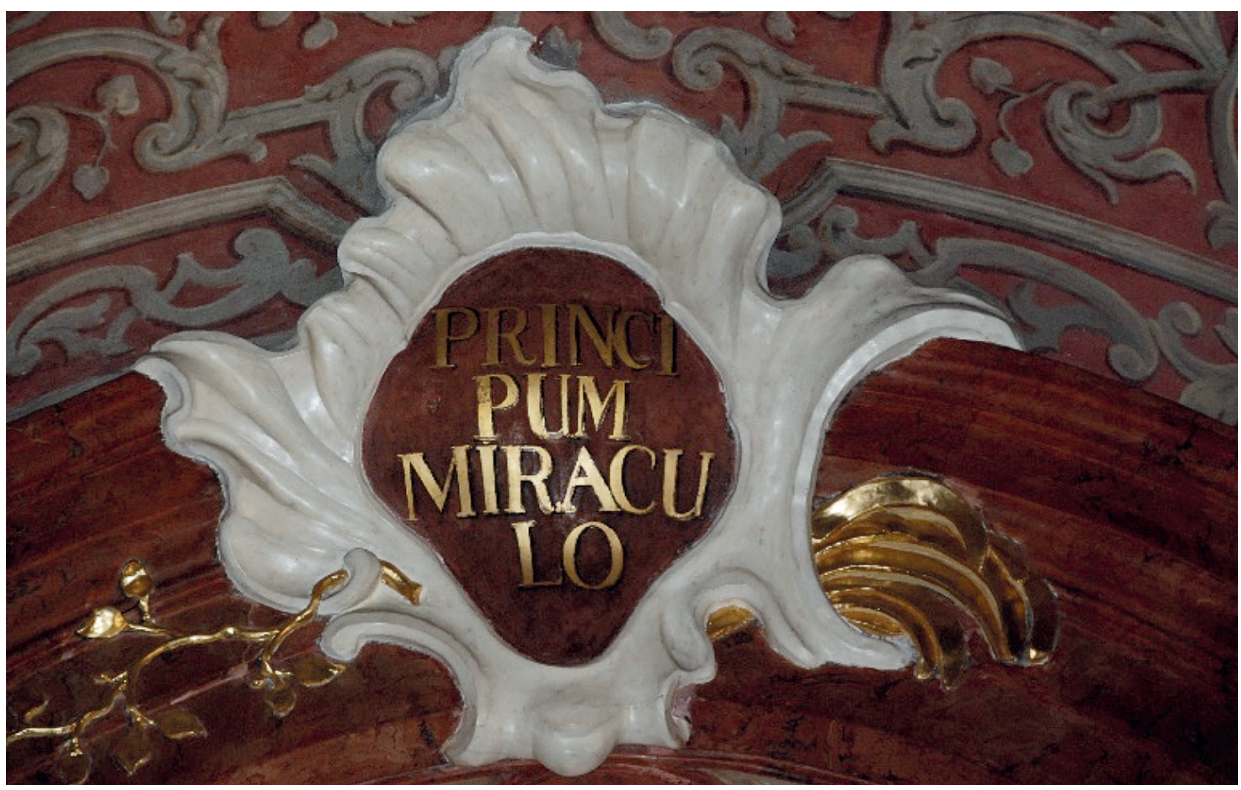

Fot. 4. Kartusz w kaplicy św. Franciszka Borgiasza

Druga inskrypcja w tej kaplicy posiada formę rozłożonego dokumentu, który trzymany jest przez putto. Łaciński tekst wpisany został w namalowany schematycznie plan kościoła i kolegium jezuitów w Poznaniu. Inskrypcja zawiera trzy błędy, które powstały zapewne podczas prac konserwatorskich. Poprawny tekst brzmi następująco:

$\{$ Jchn $\}$ ographia Collegii et Templi $\mid \mathrm{P}\{$ atr $\}$.(um) Posnaniensis Soc.(ietatis) Jesu $<\mathrm{s}>\mid$ Approbo Franciscus Borgias | Prepositus Generalis S.(ocietatis)

$$
\text { J.(esu) } \mid 1570^{9}
$$

${ }^{9}$ Litery namalowane złotą farbą na białym tle, minuskuła barokowa. Wydanie: Zwolski 1936: 28. \{Ichn\}ographia - początek wyrazu został błędnie odtworzony przez konserwatora; obecnie można by odczytać na początku $M \mathrm{z} o$ w enklawie, przy czym pierwsza kreska pionowa należała do J, natomiast $o$ to pierwotnie $c$, a druga kreska pionowa rzekomego $M$ była początkiem litery $h$, która nie została w pełni połączona z dalszą jej częścią; łaciński wyraz ichnographia 'plan podstawy budynku' jest poświadczony od czasów Witruwiusza (1.2.2); por. Zwolski (1936: 28), który wyraz ten odczytuje jako Monographia, co jednak pod względem semantycznym jest nie do przyjęcia. $P\{a t r\}$. (um) - na inskrypcji wyraźnie czytamy Posn., po czym następuje wyraz Posnaniensis, dlatego w przypadku tego pierwszego wyrazu również mamy do czynienia z błędem popełnionym przez konserwatora; najbardziej prawdopodobne zarówno pod względem treściowym, jak i graficznym wydaje się, że w pierwotnej wersji było tu Patr.; por. Zwolski (1936: 28), który zamiast widocznego Posn. Posnaniensis podaje tylko Posn. Jesu $<s>-$ błędnie dopisano $s$ na końcu wyrazu; u Zwolskiego (1936: 28) jest poprawna forma bez s. Prepositus - zapis ze spotykaną często ortografią $e$ zamiast ae; Zwolski (1936: 28) przytacza inskrypcję z formą Praepositus. 
„Schemat Kolegium i Kościoła Ojców Poznańskiego Towarzystwa Jezusowego. Zatwierdzam. Fanciszek Borgiasz, Generał Towarzystwa Jezusowego. 1570"

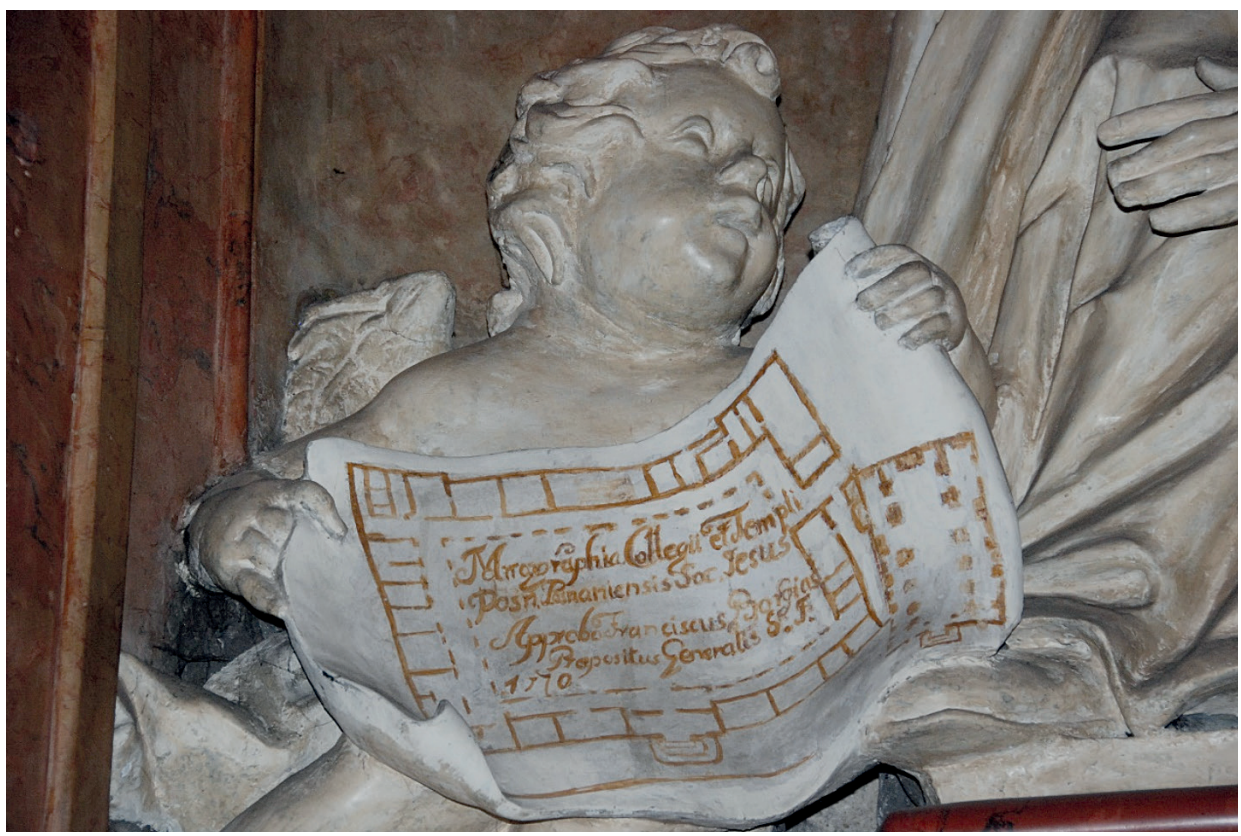

Fot. 5. Putto z inskrypcją w kaplicy św. Franciszka Borgiasza

Tekst ten nawiązuje do rzeczywistej zgody na utworzenie kolegium jezuickiego w Poznaniu wydanej przez Borgiasza w 1570 r., niemniej mamy tu do czynienia $\mathrm{z}$ anachronizmem, ponieważ projekty klasztoru i kościoła powstały niewątpliwie znacznie później (kamień węgielny pod obecny kościół został wmurowany w $1651 \mathrm{r}$.).

Następna kaplica poświęcona jest św. Alojzemu Gonzadze (1568-1591), który będąc pierworodnym synem Ferdynanda Gonzagi (1544-1586), margrabiego Castiglione delle Stiviere w Lombardii, miał prawem dziedzictwa objąć władzę po ojcu, jednakże zrzekł się tego prawa na rzecz młodszego brata Rudolfa (1569-1593) i wstąpił do zakonu jezuitów. Nie doczekał jednak święceń kapłańskich, ponieważ angażując się w pomoc chorym na epidemię panującą w Rzymie sam się zaraził i zmarł w wieku zaledwie 23 lat. Został kanonizowany w 1726 r., a wkrótce potem ogłoszony patronem studentów, obecnie zaś jest ogólnie patronem młodzieży katolickiej ${ }^{10}$. Inskrypcja znajdująca się w kartuszu nad łukiem kaplicy od strony nawy głównej określa tego świętego następująco:

\footnotetext{
${ }^{10}$ Najważniejsze epizody z żywota św. Alojzego Gonzagi opisuje Zaleski (1996: 333n.).
} 


\section{ANGELI $\mid$ CO | IUVENI ${ }^{11}$}

„Anielskiemu młodzieńcowi”

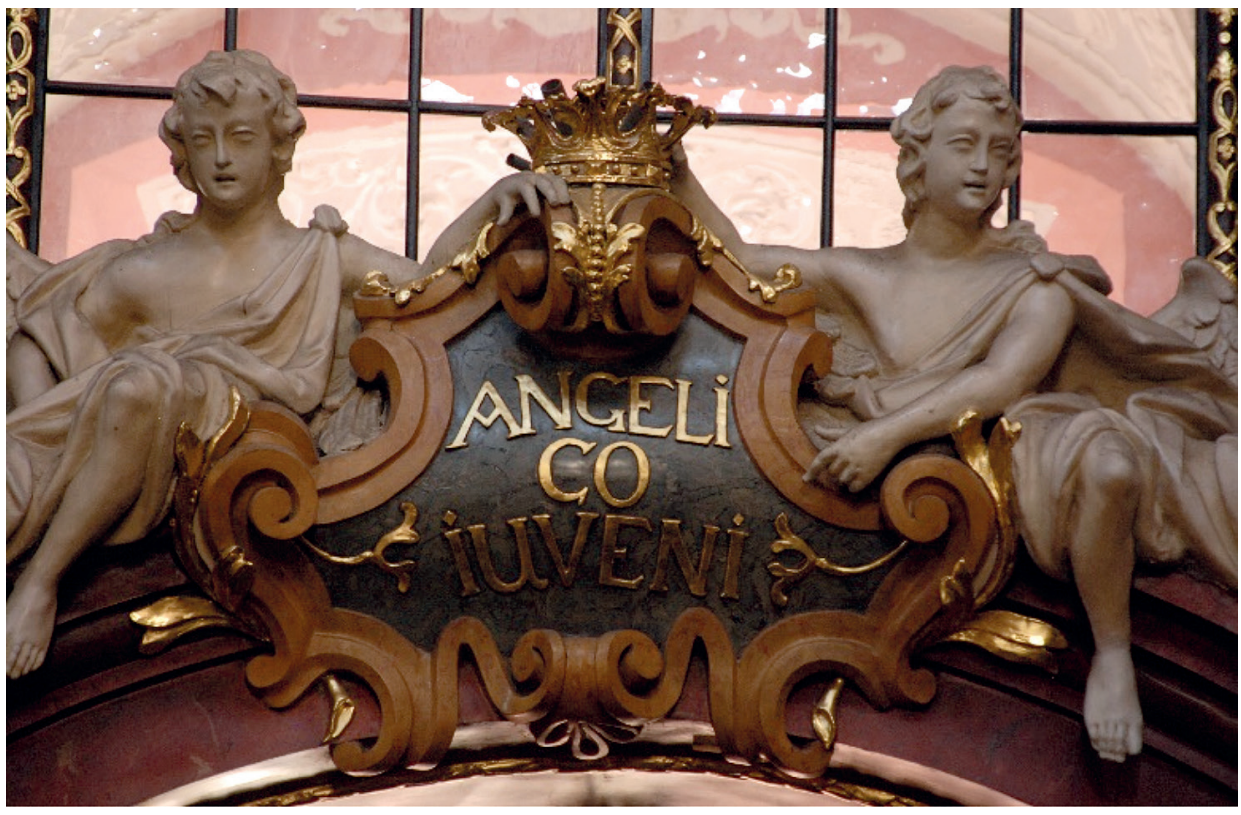

Fot. 6. Kartusz nad łukiem kaplicy św. Alojzego Gonzagi od strony nawy głównej

Nad ołtarzem w kartuszu widnieje natomiast cytat z Księgi Jeremiasza (12.7):

$$
\begin{gathered}
\text { RELIQUI | DOMUM MEAM | RELIQUI HÆREDITATEM | } \\
\text { Jer: (emiae) } 12^{12}
\end{gathered}
$$

„Pozostawiłem dom mój, pozostawiłem dziedzictwo. (Księga) Jeremiasza 12”

Cytat ten został wyciągnięty z pierwotnego kontekstu i wykorzystany w odniesieniu do św. Alojzego, co zresztą bardzo dobrze pasuje do jego żywota. W wydaniach Wulgaty przyjmuje się w drugiej części wersję dimisi hereditatem meam, co jednak nie zmienia zasadniczego sensu zdania.

Do przekazania prawa do dziedzictwa bratu Rudolfowi nawiązuje następna inskrypcja. Znajduje się ona na zwoju trzymanym przez anioła stojącego po

${ }^{11}$ Litery wypukłe, pomalowane złotą farbą na ciemnym, niemal czarnym tle, majuskuła barokowa. Wydania: Zwolski 1936: 28; Szczepaniak 1996: 30; Owczarzak 2009: 24. ANGELICO - nieoznaczone przeniesienia wyrazu.

${ }^{12}$ Litery wypukłe pomalowane złotą farbą na bordowym tle, majuskuła barokowa z minuskułą w ostatnim wersie. Wydania: Zwolski 1936: 28; Szczepaniak 1996: 30. HEREDITATEM - często spotykany zapis tego wyrazu z nieetymologicznym dyftongiem ae zamiast $e$. 


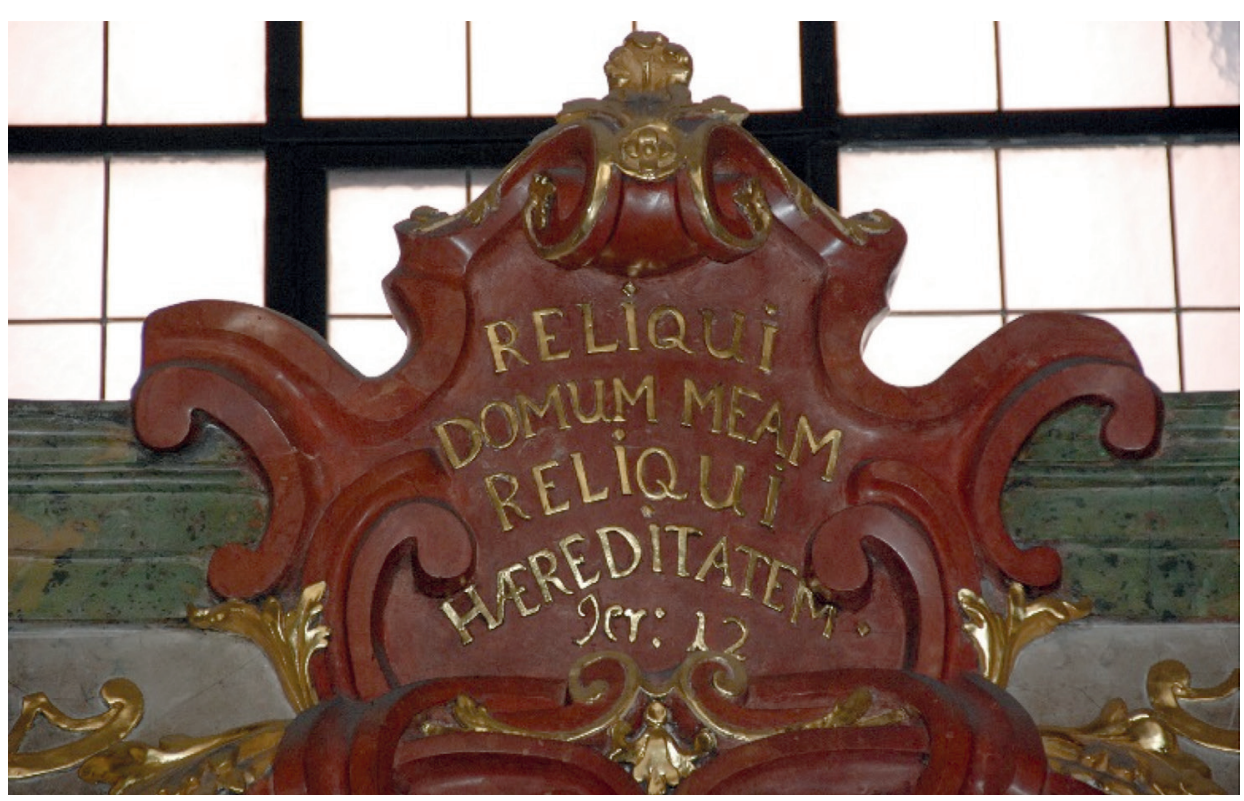

Fot. 7. Kartusz w kaplicy św. Alojzego Gonzagi

lewej stronie ołtarza. Malowany farbą tekst zawiera błędy, które powstały zapewne podczas prowadzonych na przestrzeni dziejów kilkakrotnych prac konserwatorskich. Po dokonaniu poprawek tekst brzmi następująco:

ALO $\{$ Y $\}$ SIUS GON[ZAGA] | Ferdinandi Principi[s] | Marchionis Castilionis | Stiverorum Primogen $\{\mathrm{it}\} \mathrm{o} \mid$ Avitæ Di $\{\mathrm{t}\}$ ionis Hæres Et $\mid$ Dominus Amore Christi | Rudolpho Fratri (secun)do gen $\{$ it $\}$ o | Principi Marchion $\{i\}$ cedo | Renuntio \{ALOYS\}IUS ${ }^{13}$

${ }^{13}$ Litery malowane szarą farbą (z efektem cieni stworzonych ciemną farbą) na kremowym tle, majuskuła i minuskuła barokowa. Wydanie: Szczepaniak 1996: 30. Na inskrypcji zastosowano zabieg artystyczny polegający na nie w pełni rozwiniętym zwoju, stąd też niektóre litery są niewidoczne, gdyż znajdują się rzekomo w części zwiniętej; tak jest w przypadku następujących form: GON[ZAGA] i principi [s]. Primogen $\{i t\} o$ - wyraźnie widoczna jest forma Primogentio, jednakże taki wyraz nie istnieje i niewątpliwie chodzi o primogenitum n. 'prawo pierworództwa, prawo starszeństwa'. Di $\{t$ \} ionis - omyłkowo zapisano Dilionis; Hoeres - częsty zapis z nieetymologicznym dyftongiem ae zamiast $e$ (por. formę hoereditatem na poprzedniej inskrypcji). Et-druga litera tylko czesściowo zapisana. (Secun)do - abrewiacja zapisana jako $2 d o$. Gen \{it $\} o-$ błędnie zapisano ten wyraz jako gentio. Marchion $\{i\}$ - na inskrypcji figuruje forma Marchionæ, niemniej rzekomy rzeczownik marchiona f. lub ewentualnie przymiotnik marchionus, $-a,-$ um nie są znane łacinie; z tego powodu wydaje się, że to kolejny błąd konserwatora zamiast dat. sing. Marchioni, tym bardziej że wyrażenie princeps marchio występuję również na początku tejże inskrypcji w odniesieniu do Ferdynada; \{ALOYS\}IUS $\mathrm{w}$ tej formie dobrze czytelne są jedynie ostatnie trzy litery, natomiast na początku występują dziwne znaki przypominające obecnie ym9, które zapewne są częściami liter nie w pełni odmalowanych $\mathrm{w}$ trakcie jednej z renowacji; będzie o tym mowa niżej. 
„(Ja), Alojzy Gonzaga, (syn) Ferdynanda, margrabiego Castiglione delle Stiviere, (będąc) na mocy prawa pierworództwa spadkobiercą władzy przodków i panem, z miłości do Chrystusa ustępuję urodzonemu po mnie bratu Rudolfowi, (odtąd) margrabiemu. Ogłaszam (to) publicznie. Alojzy".

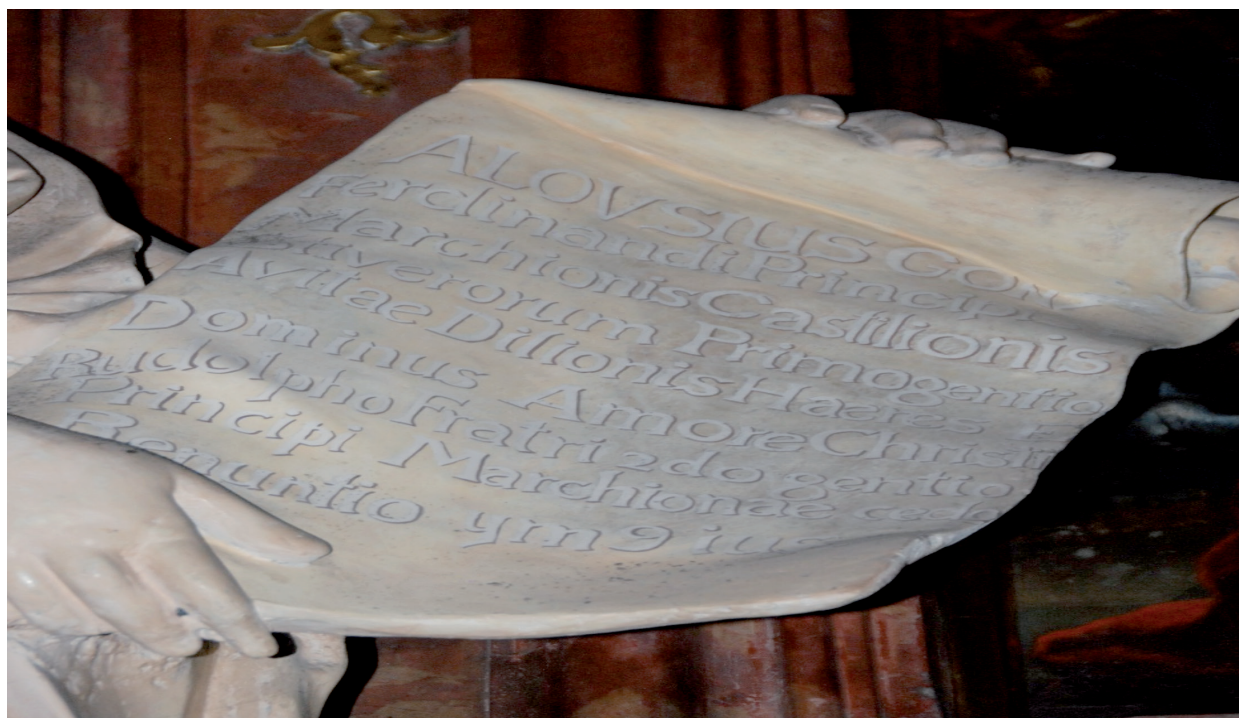

Fot. 8. Inskrypcja po lewej stronie ołtarza św. Alojzego Gonzagi

Inskrypcja ta jest imitacją dokumentu, w którym św. Alojzy zrzekł się prawa do dziedzictwa i margrabstwa na rzecz młodszego brata Rudolfa. Dotychczas nie udało się znaleźć ewentualnego pierwowzoru tego tekstu. Nie można jednak wykluczyć, że został on stworzony przez artystę pracującego nad wystrojem tej kaplicy na podstawie powszechnie znanych faktów z żywota św. Alojzego. Jeśli tak, możemy się dopatrywać wpływu treści inskrypcji ze znajdującej się dokładnie naprzeciw (w nawie wschodniej) kaplicy św. Rozalii. Chodzi tu o tekst wyryty wedle tradycji przez samą świętą w grocie na Górze Quisquinie ${ }^{14}$. Na taki wpływ mogłaby także wskazywać ciekawa paralela, jaką jest wyrażenie amore Christi, czyli „z miłości do Chrystusa”, widniejące na obu inskrypcjach. Nie ulega też wątpliwości, że artysta starał się upodobnić kaplicę św. Alojzego do kaplicy św. Rozalii, o czym świadczy umieszczenie rzeźb dwóch aniołów

${ }^{14}$ Tekst tej inskrypcji w kaplicy św. Rozalii przedstawia się następująco: ROSALIA SINIBALDI | QUISQUINÆ ET ROSA |RUM DOMINI FILIA | AMORE CHRISTI IN HOC | ANTRO HABITARE DECREVI ,(Ja), Rozalia, córka Sinibalda, pana (Góry) Quisquiny i (Góry) Róż, z miłości do Chrystusa postanowiłam zamieszkać w tej grocie”. Ten sam tekst - z niewielkimi tylko odstępstwami - znajdziemy w pierwszym żywocie św. Rozalii pt. De vita et inventione S. Rosaliae (O życiu i odkryciu św. Rozalii) z 1631 r. autorstwa jezuity Giordano Casciniego. 
na ołtarzu. O ile w przypadku św. Rozalii ich obecność jest całkiem zrozumiała, ponieważ anioły miały ją odprowadzić do groty, o tyle w odniesieniu do św. Alojzego brak podobnych punktów zaczepienia w żywocie.

Najbardziej kontrowersyjną częścią inskrypcji są trzy dziwne znaki w ostatnim wyrazie, które prawdopodobnie stanowiły początek imienia Alojzego. Jeśli interpretacja ta jest słuszna, mielibyśmy tu do czynienia ze stylizacją jego podpisu. W obecnej wersji wprawdzie trudno pod względem paleograficznym dopatrzyć się - nie licząc trzech ostatnich liter ius - imienia świętego, niemniej przed kompleksową renowacją naw bocznych kościoła przeprowadzoną w 2007 r. $^{15}$ cała inskrypcja wyglądała nieco inaczej. Przede wszystkim namalowana była złotą farbą, a kontrowersyjne litery na końcu dawały się o wiele bardziej powiązać z imieniem Alojzego. Poniżej znajduje się przerys ostatniego wyrazu z wersji sprzed renowacji wraz z przypuszczalną rekonstrukcją, przy czym pierwsza litera miała prawdopodobnie nieco bardziej ozdobny kształt:

\section{YMmilus \\ ALOYSIUS}

Po prawej stronie ołtarza znajduje się rzeźba drugiego anioła, który trzyma otwartą księgę. Na obu stronach księgi widnieją napisy:

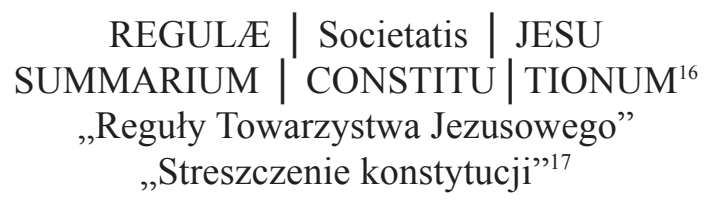

Umieszczenie reguł i konstytucji w formie streszczenia w jednej księdze nie jest tu jedynie artystyczną inwencją, lecz odnosi się do ważnej na wczesnym etapie istnienia Towarzystwa Jezusowego niespełna trzydziestostronicowej broszury pt. Quaedam ex constitutionibus cum regulis communibus Societatis excerpta (Pewne ekscerpty z konstytucji wraz z regułami ogólnymi Towarzystwa). Ta wydana po raz pierwszy w Rzymie w 1560 r. książeczka składa się właśnie z dwóch

\footnotetext{
${ }^{15} \mathrm{O}$ renowacji vide Błaszczyk 2008: 63-66.

${ }^{16}$ Litery malowane szarą farbą (z efektem cieni stworzonych ciemną farbą) na kremowym tle, majuskuła i minuskuła barokowa. Wydania: Zwolski 1936: 28; Szczepaniak 1996: 30. Societatis Zwolski 1936: 28 notuje Soc. CONSTITUTIONUM - brak oznaczenia przeniesienia wyrazu; litera $O$ w trzecim wersie jest widoczna jedynie częściowo (jakby zasłonięta lewym kciukiem anioła).

${ }^{17}$ Chodzi tu o konstytucje w liczbie mnogiej.
} 


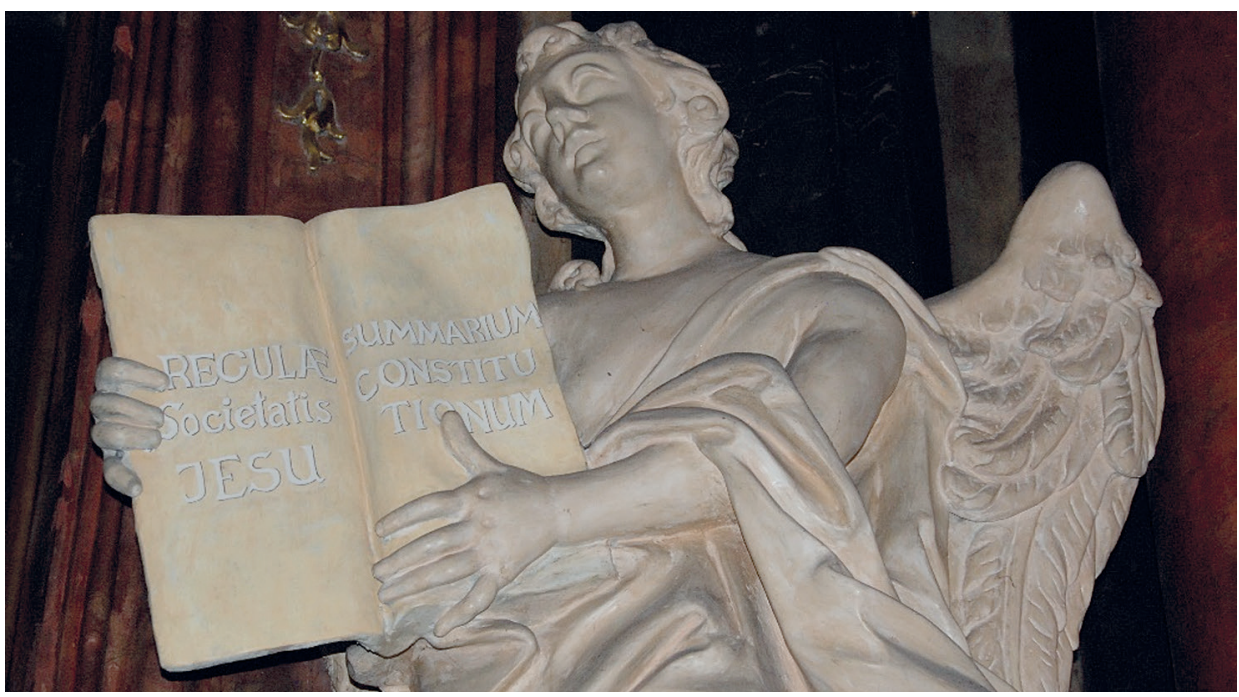

Fot. 9. Inskrypcja po prawej stronie ołtarza św. Alojzego Gonzagi

części: Summarium constitutionum i Regulae communes ${ }^{18}$. Przygotowanie skróconej wersji konstytucji i reguł Towarzystwa stało się niejako koniecznością ze względu na ich znaczne rozmiary. Odtąd nowicjusze i potencjalni kandydaci mogli stosunkowo szybko zapoznać się z ogólnymi zasadami i wymogami zakonnymi, a dopiero na dalszym etapie przystępowali do przestudiowania szczegółowych konstytucji i reguł. Tak również zaczynał zapewne św. Alojzy, który - jak wspomniano - zmarł młodo, nie doczekawszy święceń kapłańskich.

Pierwsza kaplica nawy wschodniej była pierwotnie miejscem, gdzie rozdawano chleb ubogiej ludności miasta ${ }^{19}$. Poświęcona jest ona św. Janowi Franciszkowi Regisowi (1597-1640), francuskiemu jezuicie, chociaż dawniej uważano, że patronem kaplicy jest św. Jan Jałmużnik (VI/VII w. $)^{20}$. Centralne miejsce w kaplicy zajmuje grupa rzeźbiarska przedstawiająca świętego wraz z mężczyzną proszącym go o jałmużnę i puttem. Wizerunek ten jest związany z jego działalnością na rzecz ubogich i chorych (zwłaszcza kobiet i dzieci). W kaplicy znajdujemy tylko jedną inskrypcję umieszczoną w kartuszu wysoko ponad grupą rzeźbiarską:

\footnotetext{
${ }^{18}$ Tekst broszury znajduje się w: Sancti Ignatii de Loyola Constitutiones et Regulae Societatis Jesu, t. III: Regulae Societatis Iesu (1540-1556), ed. D.F. Zapico, Roma 1948, 545-565 (Appendix II i III).

${ }^{19}$ Vide Zwolski 1936: 27; Szczepaniak 1996: 30.

${ }^{20}$ O kaplicy św. Jana Jałmużnika piszą np. Zwolski (1936: 27), Dubowski (1956: 201) i Szczepaniak (1996: 30). W nowszych publikacjach podaje się, że jest to kaplica św. Jana Franciszka Regisa; vide Kurzawa - Kusztelski 1998: 22; Błaszczyk 2008: 63; Lewandowski 2009: 100; Owczarzak 2009: 25.
} 


\section{PATRI | PAUPE $\mid$ RUM $^{21}$}

„Ojcu ubogich"

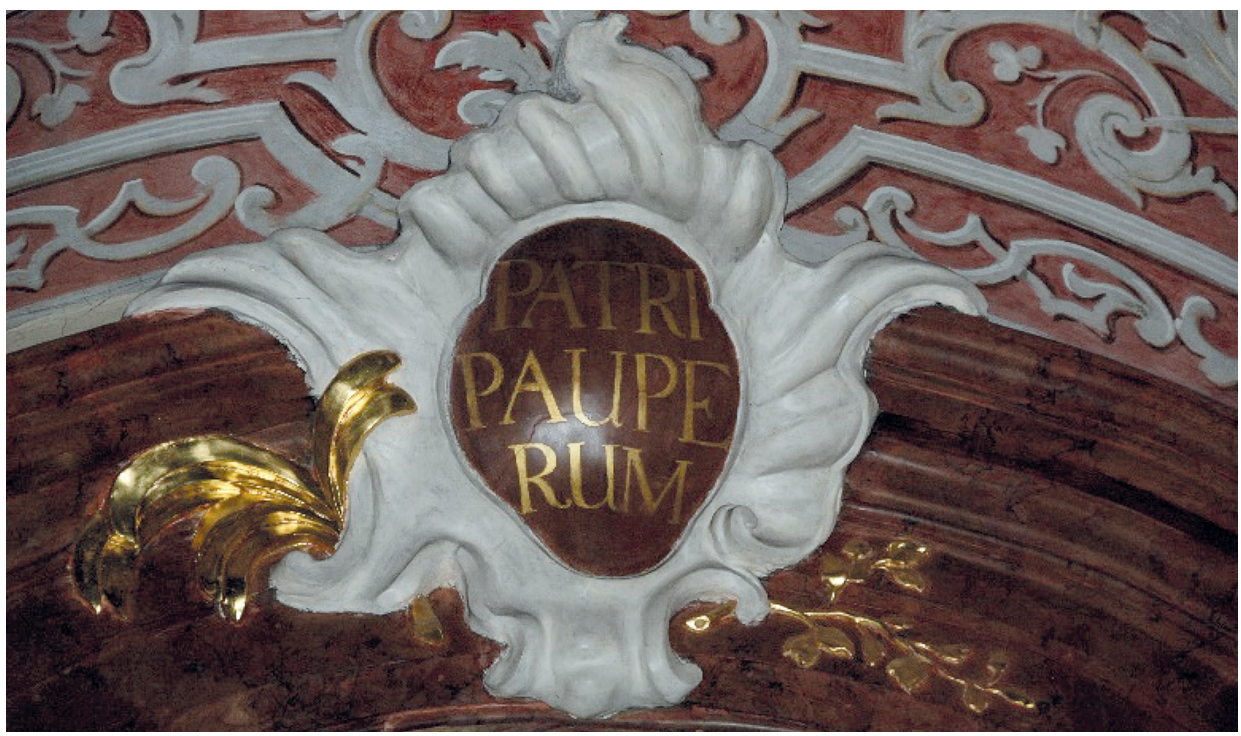

Fot. 10. Kartusz w kaplicy św. Jana Franciszka Regisa

O tym, że miano pater pauperum, którym często określano ludzi nader zaangażowanych w pomoc ubogim i potrzebującym, było używane także w odniesieniu do św. Jana Franciszka Regisa, świadczy dokument sporządzony o nim w 1710 r. do celów beatyfikacyjnych i kanonizacyjnych przez Świętą Kongregację Obrzędów (beatyfikacja nastąpiła w 1719 r., kanonizacja - w 1737 r.). Znajdujemy w nim m.in. następujące zdanie: „Paupertatis, ac pauperum erat amantissimus, et qui erat filius paupertatis, ut Matris, etiam Patris Pauperum, ac Sancti nomine vulgo appellabatur”. („Najbardziej umiłował on biedę i ubogich, i, samemu będąc synem biedy, powszechnie był nazywany zarówno matką, jak i ojcem ubogich, a także świętym"²2). Jeśli chodzi natomiast o źródła określenia pater pauperum, wypada w pierwszym rzędzie zwrócić uwagę na powstałą w średniowieczu tzw. Sekwencję do Ducha Świętego (Veni, Sancte Spiritus... „Przybądź, Duchu Święty...”) wykonywaną podczas liturgii w niedzielę Zesłania Ducha Świętego. W drugiej zwrotce tego utworu Duch Święty jest przywoływany m.in. słowami: Veni, Pater pauperum!, „Przybądź, Ojcze ubogich!”.

${ }^{21}$ Litery malowane złotą farbą na bordowym tle, majuskuła barokowa. Wydania: Szczepaniak 1996: 30 (z błędnym odczytem i tłumaczeniem: airi pauperum, ,na pieniądze dla biednych”); Owczarzak 2009: 25. PAUPERUM - brak oznaczenia przeniesienia wyrazu.

${ }^{22}$ Beatificatio et canonizatio ven. servi Dei Ioannis Francisci Regis Sacerdotis Professi Societatis Iesu: 13. 
Odnośnie do tej inskrypcji Szczepaniak ${ }^{23}$ podaje, że pierwotnie brzmiała ona inaczej, mianowicie pauperibus panem, „ubogim chleba” i że później zmieniono tekst na obecny. Zapewne zaczerpnął on tę informację z przedwojennego przewodnika po farze autorstwa Zwolskiego ${ }^{24}$. Autor ten nie wspominając w ogóle o wyrażeniu patri pauperum pisze: „Rozdawano tu ubogim chleb. Stąd figura św. Jana Jałmużnika z napisem: pauperibus panem - oraz scena z życia św. Jana na suficie". Zwolski nie jest precyzyjny w swoim opisie, stąd brak pewności, czy faktycznie miał on na myśli inskrypcję w kartuszu. Jeśli tak, należałoby przyjąć, że napis został zmieniony w trakcie prac konserwatorskich przeprowadzonych w latach $1948-50^{25}$.

Warto jednak zwrócić uwagę na fakt, że w grupie rzeźbiarskiej w kaplicy istnieje jeszcze jedno potencjalne miejsce na inskrypcję. Mowa tu o otwartej księdze niedużych rozmiarów zwróconej w kierunku wnętrza kościoła, którą trzyma putto usadowione po prawej stronie grupy rzeźbiarskiej. Najprawdopodobniej tu także pierwotnie istniała krótka inskrypcja malowana, która z upływem czasu wypłowiała i nie została odnowiona. Może więc przed wojną w kartuszu znajdował się napis patri pauperum, natomiast w księdze pauperibus pa$n e m$ ? Na taką interpretację w dużej mierze pozwala lapidarny opis Zwolskiego, tj. „figura św. Jana Jałmużnika z napisem: pauperibus panem", przy czym trzeba by założyć, że autor przewodnika przeoczył inskrypcję w kartuszu u szczytu ołtarza.

W trzeciej kaplicy nawy wschodniej uczczono trzech męczenników jezuickich, którzy w wyniku prześladowań zostali ukrzyżowani w Japonii w 1597 r. Należą oni do grupy 26 męczenników kościoła katolickiego, znanych jako św. Męczennicy z Nagasaki lub św. Paweł Mika i jego Towarzysze. Oprócz trzech jezuitów ukrzyżowano wówczas sześciu franciszkanów i siedemnastu tercjarzy franciszkańskich. Męczennicy jezuiccy, którzy byli Japończykami, to wspomniany św. Paweł Mika (1565-1597) oraz

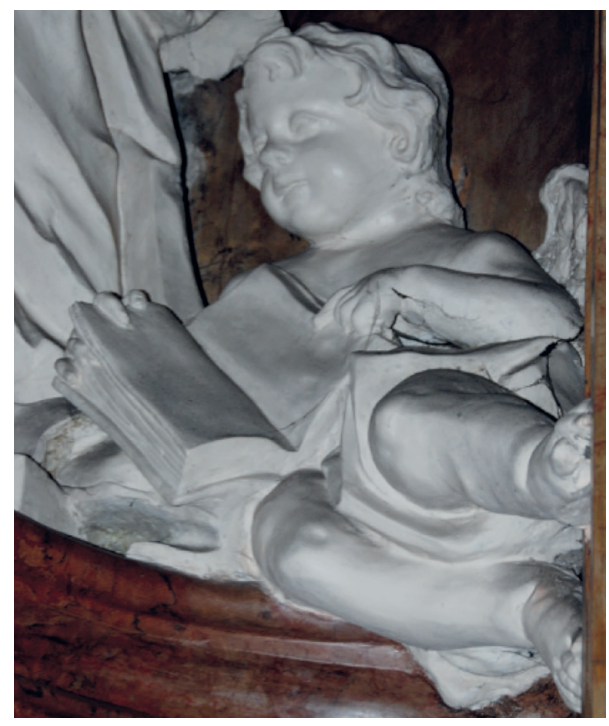

Fot. 11. Putto z księgą w kaplicy św. Jana Franciszka Regina

\footnotetext{
${ }^{23}$ Szczepaniak 1996: 30.

${ }^{24}$ Zwolski 1936: 27.

${ }^{25} \mathrm{O}$ prowadzeniu prac konserwatorskich nawy wschodniej w tym czasie wspomina Błaszczyk (2008: 64).
} 
św. Jan Sōan (1578-1597) i św. Jakub Kisai (1533-1597) ${ }^{26}$. Właśnie tych trzech świętych przedstawia obraz z ok. 1745 r. umieszczony w ołtarzu, przed którym ustawiono figurę Jezusa Bolesnego z połowy XV w. przeniesioną z dawnej Kolegiaty św. Marii Magdaleny ${ }^{27}$. O tym, komu poświęcona jest kaplica, informuje także inskrypcja wpisana w kartusz na łuku od strony nawy głównej:

\section{SOCIETA | TIS IESU | MARTYRIBUS ${ }^{28}$ \\ „Męczennikom Towarzystwa Jezusowego"}

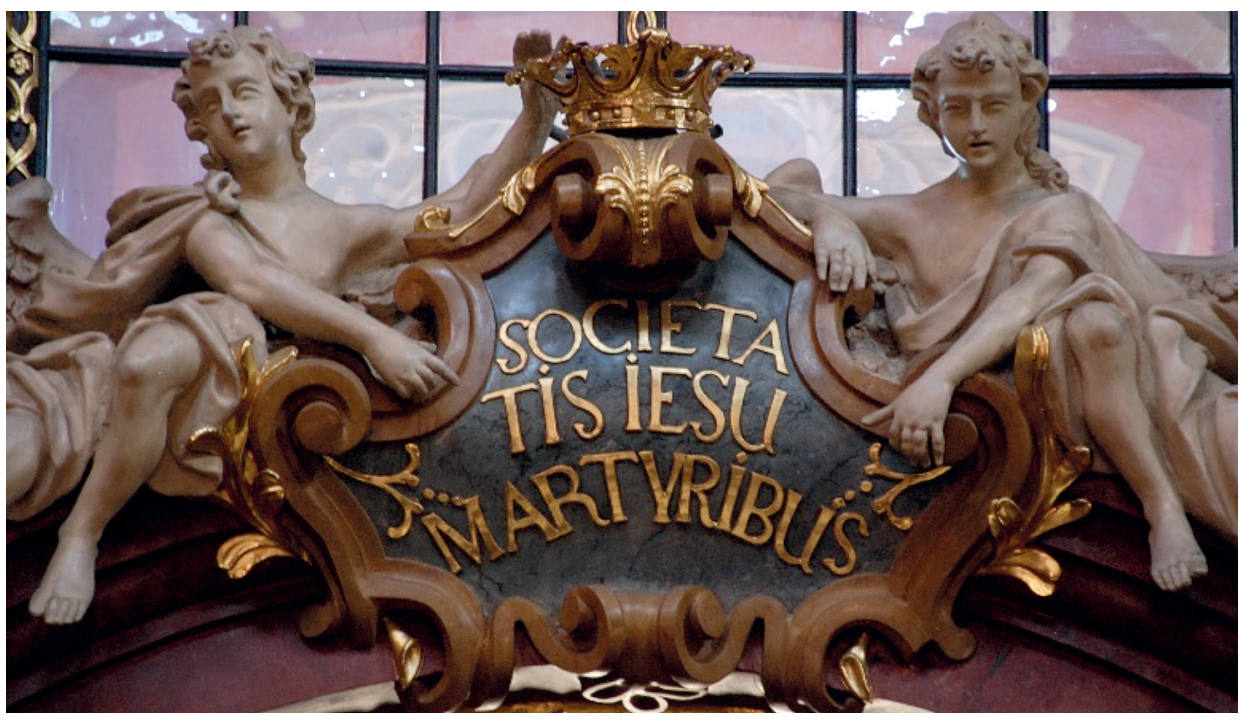

Fot. 12. Kartusz nad łukiem kaplicy św. Męczenników Jezuickich od strony nawy głównej

Dwie następne inskrypcje widnieją w kartuszach trzymanych przez putta umieszczone po bokach ołtarza. Obie składają się na jeden cytat z Dziejów Apostolskich (9.15):

\section{CO |RAM GEN | TIBUS ET | REGIBUS | acto(rum) (Apostolorum) | $9^{29}$ „Ku narodom i władcom. Dzieje Apostolskie 9"}

${ }^{26}$ O św. Męczennikach z Nagasaki vide Zaleski 1996: 79-80.

${ }^{27} \mathrm{Na}$ temat obrazu i rzeźby vide Kurzawa - Kusztelski 1998: 21 z fig. 172 i 433.

${ }^{28}$ Litery wypukłe, pomalowane złotą farbą na ciemnym (niemal czarnym) tle, majuskuła barokowa. Wydania: Zwolski 1936: 25; Szczepaniak 1996: 28; Owczarzak 2009: 26. SOCIETATIS - przeniesienie wyrazu bez zaznaczenia.

${ }^{29}$ Litery malowane złotą farbą na brązowym tle, majuskuła barokowa, a także minuskuła barokowa w wyrazie acto(rum). Wydania:. Zwolski 1936: 26; Szczepaniak 1996: 28. CORAM przeniesienie wyrazu oznaczone dwiema kreskami u dołu. GENTIBUS - litery NiT są niepełne (niejako przysłonięte obramowaniem kartusza); brak znaku przeniesienia wyrazu. 


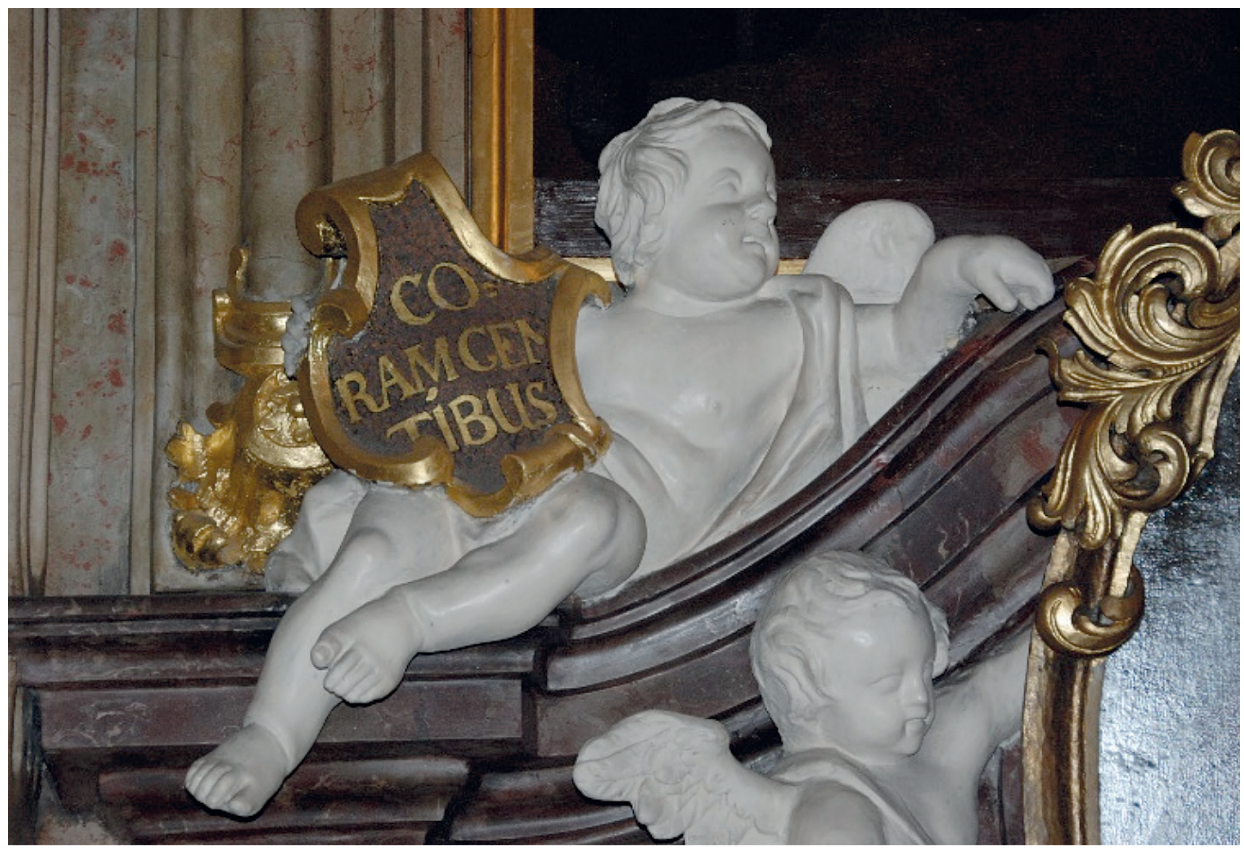

Fot. 13. Kartusz po lewej stronie ołtarza w kaplicy św. Męczenników Jezuickich

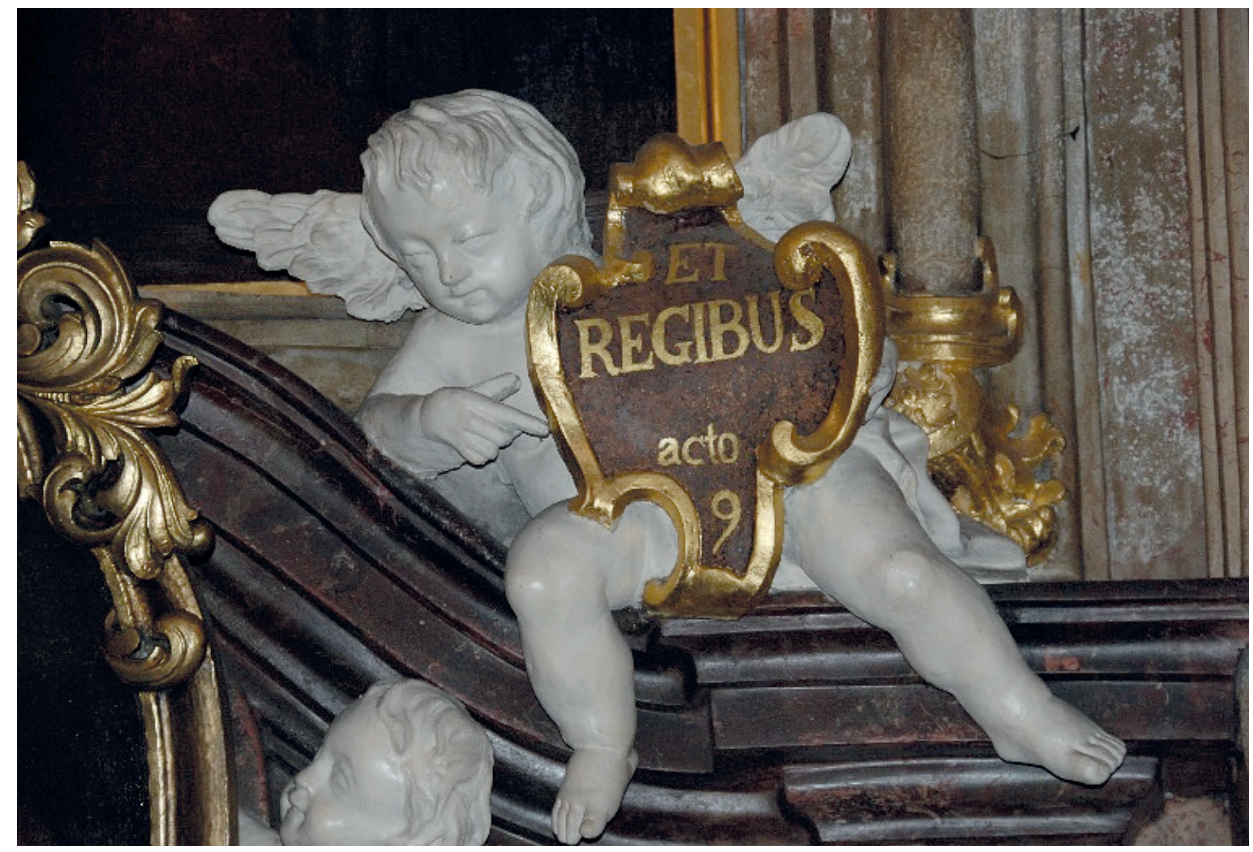

Fot. 14. Kartusz po prawej stronie ołtarza w kaplicy św. Męczenników Jezuickich 
W Dziejach Apostolskich wyrażenie to pojawia się w związku ze św. Pawłem, który dzięki swojej działalności ewangelizacyjnej nazywany jest Apostołem Narodów. Słowa te wypowiada Jezus, przekonując Ananiasza, aby udał się do Pawła (wówczas jeszcze Szawła). Całe zdanie w przekładzie Biblii Tysiąclecia brzmi następująco: „Idź - odpowiedział mu Pan - bo wybrałem sobie tego człowieka za narzędzie. On zaniesie imię moje do pogan i królów, i do synów Izraela". Zdanie to może być traktowane jako motto misjonarzy, dlatego bardzo dobrze pasuje do kontekstu jezuitów działających na Dalekim Wschodzie.

Na sklepieniu kaplicy umieszczone zostało malowidło przedstawiające słynną scenę Kazania na Górze. Jezus znajduje się w otoczeniu uczniów, z których jeden trzyma otwartą księgę z następującym napisem:

\section{BEATI | QUI PER | SECUTI|[O]N[E]M | [PA]|[T]I[UN]TUR [PRO]PTE[R] | [I]UST |[I]TIAM ${ }^{30}$}

„Błogosławieni, którzy cierpią prześladowanie dla sprawiedliwości” ${ }^{11}$

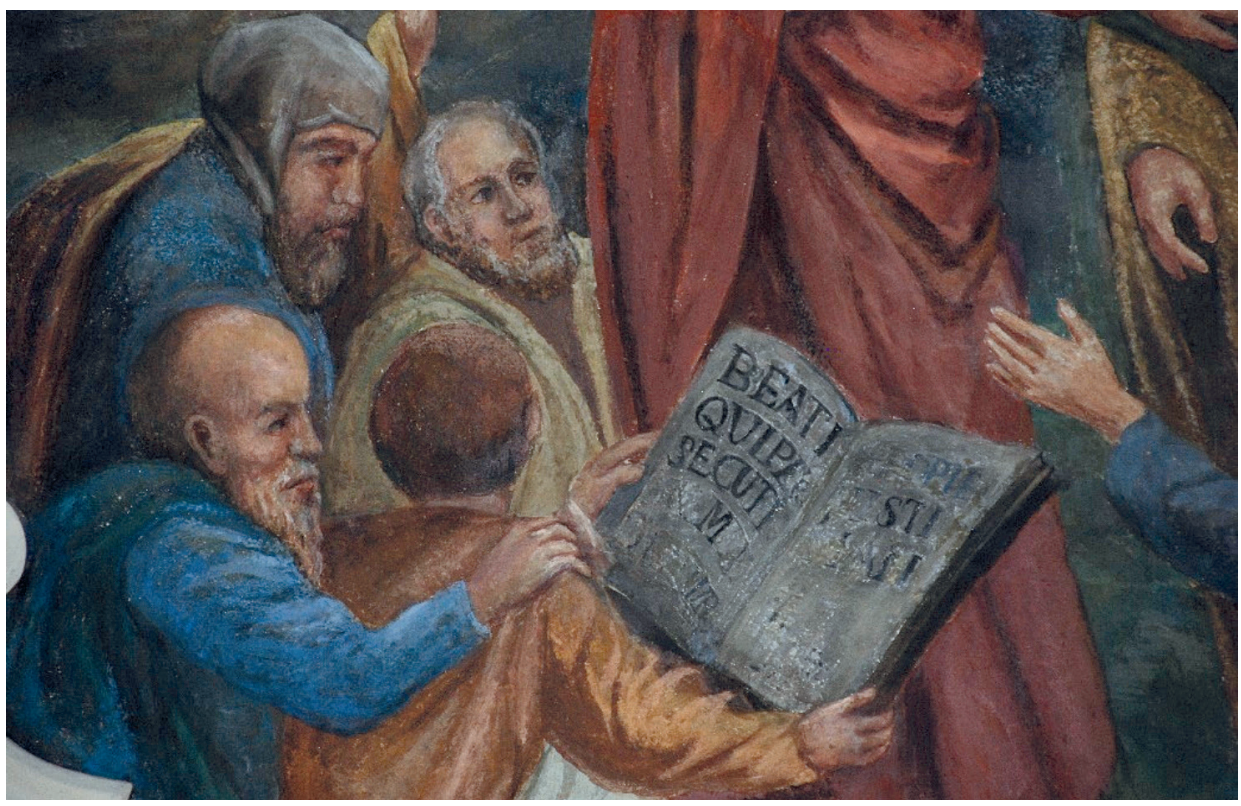

Fot. 15. Szczegół z malowidła na sklepieniu w kaplicy św. Męczenników Jezuickich

${ }^{30}$ Litery malowane czarną farbą na szarym tle (wyjątek stanowią litery PTE w wyrazie PROP$T E R$, które mają kolor niebieski), majuskuła. Wydania:. Zwolski 1936: 26; Szczepaniak 1996: 28. Niektóre litery bardzo słabo widoczne lub nawet nieczytelne. Litera $U$ ma kształt pomiędzy $U$ a $V$ (kreski pionowe są skośne, ale u dołu widoczne zaokrąglenie). Przeniesienia wyrazów bez zaznaczenia. PERSECUTIONEM - litera $R$ jest mniejsza od pozostałych.

${ }^{31}$ Przekł. BT. 
Mamy tu do czynienia z cytatem z Ewangelii św. Mateusza (5.10), stanowiącym ostatnie spośród ośmiu błogosławieństw. Druga część zdania w przekładzie Biblii Tysiąclecia brzmi: „(...) albowiem do nich należy królestwo niebieskie”. Niewątpliwie cytat ten jest nader adekwatny w odniesieniu do św. Męczenników.

Kolejna kaplica dedykowana jest św. Franciszkowi Ksaweremu i nieprzypadkowo znajduje się tuż obok umieszczonego w transepcie ołtarza jego bliskiego przyjaciela, św. Ignacego Loyoli, z którym współtworzył Towarzystwo Jezusowe. Św. Franciszek zasłynął przede wszystkim z działalności misyjnej, będąc pierwszym misjonarzem jezuickim. Dokładał on wszelkich starań, aby ewangelizować i tworzyć struktury kościelne na terenach Indii i na pobliskich wyspach, gdzie przebywał w latach 1542-1549, skąd następnie wyruszył dalej na Wschód do Japonii i Chin ${ }^{32}$. Właśnie do jego działalności w Indiach odwołuje się inskrypcja w kartuszu nad łukiem od strony nawy głównej:

\section{INDIA | RUM | APOSTOLO ${ }^{33}$ „Apostołowi Indii”}

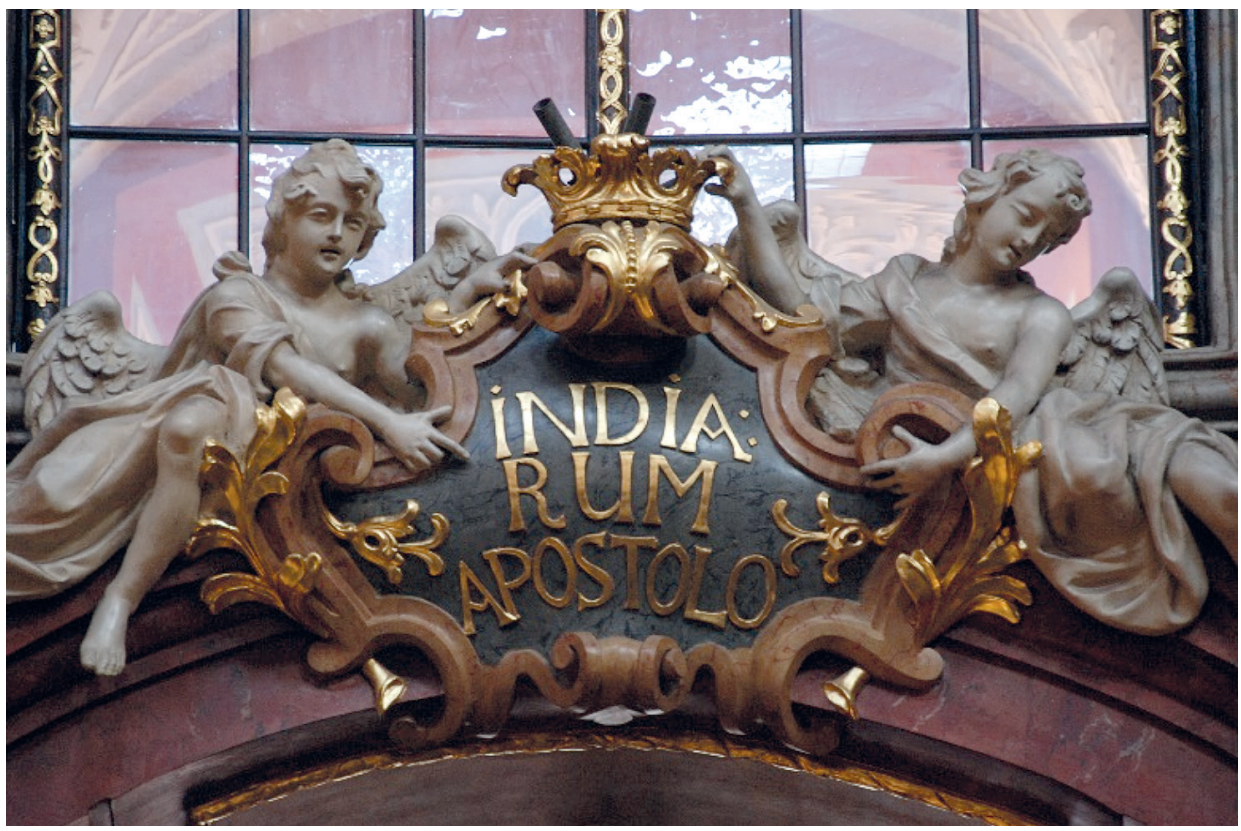

Fot. 16. Kartusz nad łukiem kaplicy św. Franciszka Ksawerego od strony nawy głównej

${ }^{32}$ O św. Franciszku Ksawerym vide Zaleski 1996: 767-770.

${ }^{33}$ Litery wypukłe, pomalowane złotą farbą na ciemnym (niemal czarnym) tle, majuskuła barokowa. Wydania: Zwolski 1936: 25; Szczepaniak 1996: 28; Owczarzak 2009: 26. INDIARUM - przeniesienie wyrazu zaznaczone dwukropkiem. 
$\mathrm{Z}$ kolei w kartuszu nad ołtarzem znajduje się cytat z modlitwy rozpoczynającej się słowami O Deus, ego amo te („O Boże, kocham Cię”):

SICUT TU | AMASTI ME | SIC AMO | ET AMABO TE ${ }^{34}$ „Tak jak Ty umiłowałeś mnie, tak ja miłuję i będę miłował Ciebie”

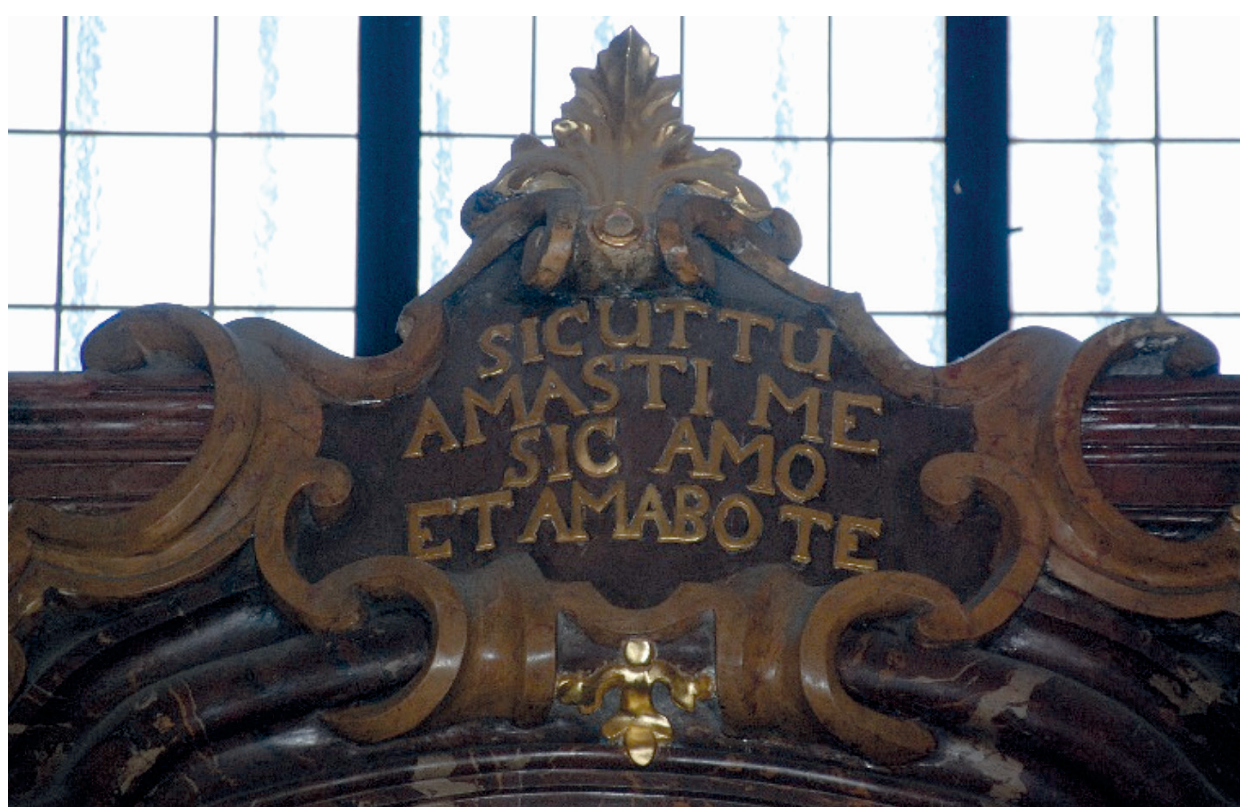

Fot. 17. Kartusz w kaplicy św. Franciszka Ksawerego

Cytat ten to 18 i 19 wers modlitwy, którą powszechnie nazywa się Modlitwą św. Franciszka Ksawerego, przy czym datacja i autorstwo tej rozbudowanej wersji łacińskiej są trudne do ustalenia. Na marginesie warto wspomnieć, że w Polsce znana jest oparta na tej samej tradycji krótka modlitwa św. Franciszka Ksawerego zaczynająca się od słów: „Nie dla nagrody kocham Cię, mój Panie!”.

W retabulum ołtarza centralne miejsce zajmuje obraz przedstawiający wizję św. Franciszka Ksawerego. Obraz ten jest specyficzny, gdyż głowa świętego została namalowana na blasze miedzianej i pierwotnie była samodzielnym obrazem, a dopiero w 1743 r. została wkomponowana w obraz płócienny (z aplikacjami, tj. nimbami świętego i Chrystusa, niewielkim krzyżem i naramiennikiem) i wstawiona do ołtarza ${ }^{35}$. Na wewnętrznej stronie wspomnianej blachy znajduje

${ }^{34}$ Litery wypukłe pomalowane złotą farbą na ciemnobrunatnym tle, majuskuła barokowa. Wydania: Zwolski 1936: 25; Szczepaniak 1996: 28.

${ }^{35}$ Obraz ten szczegółowo omawia Kurzawa (1997: 279-283); vide także Kurzawa - Kusztelski 1998: 21 i fig. 328. 
się łacińska inskrypcja. Oczywiście obecnie jest ona niewidoczna, znamy jednak jej treść dzięki odpisowi dokonanemu podczas konserwacji obrazu w roku 1913 przez ks. Antoniego Laubitza (1861-1939), późniejszego biskupa pomocniczego gnieźnieńskiego. Odpis ten zachował się w liście ks. Laubitza do ówczesnego proboszcza fary, ks. Antoniego Stychla ${ }^{36}$. Już wtedy inskrypcja była słabo czytelna, o czym wspomina nadawca listu: „Tekst napisu, który częściowo prawie nieczytelny, przesyłam Ci do akt, bo po przymocowaniu blachy będzie odtąd niedostępny". Zapewne z powodu złego stanu zachowania inskrypcji odpis zawiera sporo błędów, po skorygowaniu których tekst przedstawia się następująco:

Haec imago S.(ancti) Francisci Xavierii Indiarum Apostoli ex $\operatorname{arch}\{\mathrm{e}\}$ $\mathrm{t}<\mathrm{r}>$ ypo Romano per Rev.(erendissimi) Dom.(ini) patr $\{$ is $\}$ Paczanowski, tunc provinciali[s] Polonia[e] procurat\{ion\}em allato depicta, Templo Soc.(ietatis) Jes.(u) Coll.(egii) Posnan.(iensis) applicata a patre Gasparo Mietelski eiusdem Soc.(ietatis) A.(nno) Dom.(ini) $166\{6\} 21$ Augusti.

Eadem imago A.(nno) Dom.(ini) $17\{4\} 3$ novo altari applicata superinduto alio brachiali, ita ut huius tantum facies appareat. ${ }^{37}$

„Ten obraz świętego Franciszka Ksawerego, apostoła Indii, odmalowany $\mathrm{z}$ oryginału rzymskiego przywiezionego dzięki staraniom wielebnego ojca Paczanowskiego, wówczas prowincjała polskiego, został wstawiony do kościoła Towarzystwa Jezusowego w kolegium poznańskim przez ojca Kaspara Mietelskiego dnia 21 sierpnia roku Pańskiego 1666.

Tenże obraz w roku Pańskim 1743 został wstawiony do nowego ołtarza, tak że - po nałożeniu innego naramiennika - tylko twarz z niego jest widoczna" ${ }^{38}$.

\footnotetext{
${ }^{36}$ List ten został napisany pismem odręcznym i wysłany 5 września $1913 \mathrm{r}$. z Inowrocławia, obecnie natomiast przechowywany jest w Archiwum Archidiecezjalnym - KF 774 (dokumenty niepaginowane). Obszerne passusy z tego listu przytacza Kurzawa (1997: 280-282).

${ }^{37}$ Brak informacji na temat charakterystyki inskrypcji. Dostępny odpis w Archiwum Archidiecezjalnym (vide przyp. poprzedni). Wydanie: Kurzawa 1997: 283, przyp. 4 (na podstawie odpisu). Archetypo - w odpisie i publikacji Kurzawy (1997: 283, przyp. 4) jest architrypo. Patris - w odpisie i u Kurzawy (1997: 283, przyp. 4) widnieje patrem. Provincialis Poloniae - Kurzawa (1997: 283, przyp. 4) notuje provinciali Polonia. Procurationem - w odpisie i w artykule Kurzawy (1997: 283, przyp. 4) znajdujemy procuratorem. 1666 - Kurzawa (1997: 283, przyp. 4) cytuje 1660, z czym jednak nie zgadza się fakt, że ks. Paczkowski był prowincjałem Polski od 1666 r.; warto też wspomnieć, że 21 sierpnia 1666 r. to niedziela, a właśnie w niedzielę należałoby się spodziewać uroczystego wniesienia nowego obrazu do kościoła (21 sierpnia 1660 r. to sobota). 1743 - w odpisie ks. Laubitza jest data 1793, ale Kurzawa (1997: 281) na podstawie danych dotyczących historii ołtarza poprawia na 1743. Ut - u Kurzawy (1997: 283, przyp. 4) literówka us, lecz w odpisie jest $u t$.

${ }^{38}$ Cf. przekład Kurzawy (1997: 281): „Tenże obraz św. Franciszka Xawerego, apostoła Indii, ze starodawnego wzoru rzymskiego przez czcigodnego ojca Paczanowskiego, wówczas prowincjała polskiego, po postaraniu się delegata namalowany, wstawiony do kościoła jezuickiego w Poznaniu przez ojca Kaspra Mietelskiego 21 VIII 1660 roku” oraz „Tenże obraz w 1793 [1743] r.
} 
Zgodnie z treścią inskrypcji ks. Piotr Paczanowski (1604-1667), będący prowincjałem polskim w latach $1666-1667^{39}$, postarał się o peregrynację do Polski obrazu św. Franciszka Ksawerego z kościoła Il Gesù w Rzymie. Na jego podstawie sporządzono wówczas wierną kopię, którą następnie wstawiono do nieistniejącego obecnie kościoła św. Stanisława, używanego przez jezuitów poznańskich do czasu zbudowaniem nowego kościoła ${ }^{40}$. Uroczystość umieszczenia kopii obrazu w kościele miała miejsce w niedzielę 21 sierpnia 1666 r. w obecności ks. Kaspra Mietelskiego (1626-1699), nowego rektora nowicjatu jezuickiego św. Szczepana w Krakowie (funkcję tę pełnił w latach 1666-1672) ${ }^{41}$. Jego przybycie do Poznania może sugerować, że kopia została wykonana w Krakowie i że to on właśnie przywiózł ją do Poznania ${ }^{42}$. Po zbudowaniu nowego kościoła obraz ten postanowiono umieścić w ołtarzu św. Franciszka Ksawerego. Ze względu jednak na jego niewielkie rozmiary samą twarz świętego wkomponowano w duży płócienny obraz, przykrywając dolną część popiersia naramiennikiem. Do nowego ołtarza obraz został wstawiony w $1743 \mathrm{r}$.

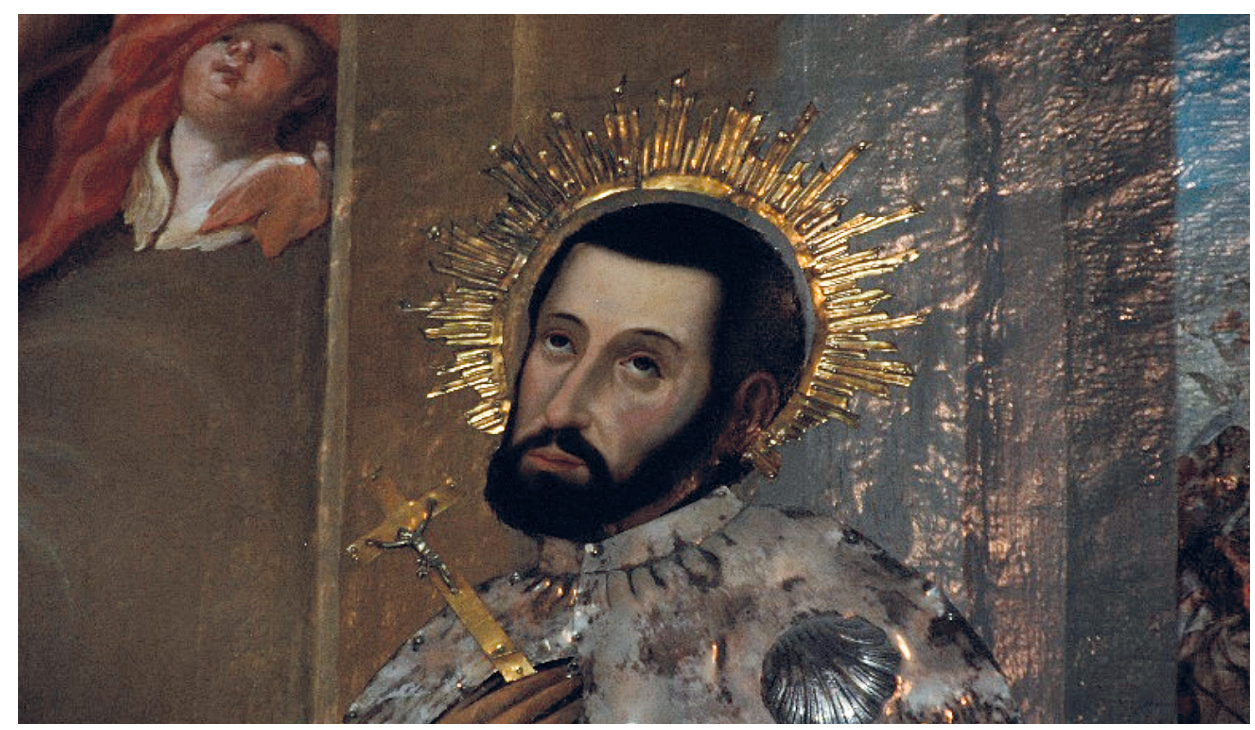

Fot. 18. Szczegół z obrazu w ołtarzu św. Franciszka Ksawerego

wstawiony do nowego ołtarza, po dodaniu innego dookoła obrazu, tak aby jego oblicze bardziej się uwidoczniło".

${ }^{39} \mathrm{Na}$ temat ks. Paczanowskiego vide Grzebień 2004: 487-488.

${ }^{40}$ Cf. Kurzawa (1997: 282), według której kopię obrazu sporządzono w Rzymie. Sugeruje ona, że ks. Paczanowski postarał się o kopię obrazu podczas pobytu w Rzymie w 1655 r. (wówczas był on delegatem na Kongregację Generalną).

${ }^{41}$ O ks. Mietelskim vide Grzebień 2004: 422.

${ }^{42}$ Przypuszczenie o tym, że kopię obrazu mógł przywieźć z Krakowa ks. Mietelski, wysuwa Kurzawa (1997: 282). 
Po lewej stronie ołtarza św. Franciszka Ksawerego znajduje się figura przedstawiająca św. Tomasza Apostoła ${ }^{43}$, obok którego stoi figura chłopca w stroju orientalnym. Chłopiec ten trzyma rozwinięty zwój z wyrytym na nim tekstem:

\section{AD INDOS SE | CONFERENS EOS | IN CHRISTIANA RE | LIGIONE ERUDIVIT | Brev:(iarium) Rom.(anum) $)^{44}$ \\ „Udając się do mieszkańców Indii, wykształcił ich w (duchu) religii chrześcijańskiej. Brewiarz Rzymski”}

Jak zaznaczono na inskrypcji, tekst pochodzi z Brewiarza Rzymskiego, a dokładniej z Breviarium Romanum ex Decreto Sacrosancti Concilii Tridentini restitutum $\mathrm{w}$ wersji autoryzowanej przez papieża Urbana VIII w 1632 r. ${ }^{45}$. W Brewiarzu tekst ten znajduje się pod dniem 21 grudnia w związku ze św. Tomaszem Apostołem (na ten dzień przypadało wspomnienie św. Tomasza aż do zmiany wprowadzonej w 1969 r.). W przekładzie na język polski początek znajdującego się w Brewiarzu opisu działalności tego świętego brzmi następująco: „Tomasz Apostoł, zwany także Didymosem, Galilejczyk, po przyjęciu Ducha Świętego wyruszył do wielu prowincji, aby głosić Ewangelię Chrystusa. Przekazał nauki wiary chrześcijańskiej i życia Partom, Medom, Persom, Hyrkanom i Baktrom. Na końcu udając się do mieszkańców Indii, wykształcił ich

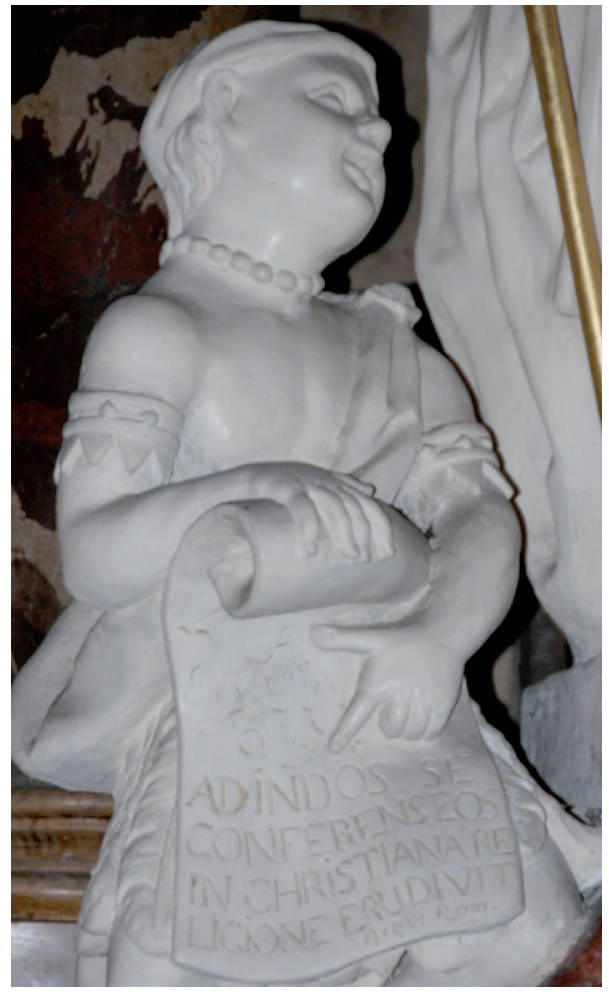

Fot. 19. Inskrypcja po lewej stronie ołtarza św. Franciszka Ksawerego

${ }^{43} \mathrm{O}$ tym, że rzeźba przedstawia św. Tomasza Apostoła, vide Kurzawa 1997: 277; Kurzawa Kusztelski 1998: 20; Lewandowski 2009: 108; Owczarzak 2009: 26. Dawniej interpretowano ją jako św. Franciszka Ksawerego; vide Zwolski 1936: 25; Dubowski 1956: 202-203; Szczepaniak 1996: 28.

${ }^{44}$ Litery wklęsłe ze śladami złotej farby, majuskuła barokowa oraz minuskuła barokowa w ostatnich dwóch wyrazach Wydania: Zwolski 1936: 25; Szczepaniak 1996: 28; Kurzawa 1997: 277. RELIGIONE - przeniesienie wyrazu bez zaznaczenia.

${ }^{45}$ Pierwotną wersję potrydenckiego Brewiarza Rzymskiego wydał papież Pius V w 1568 r., która została następnie dostosowana do kalendarza gregoriańskiego przez papieża Klemensa VIII w 1602 r.; więcej na temat Brewiarza Rzymskiego vide Danielski 1976: 1067-1068. 
w (duchu) religii chrześcijańskiej” (s. 787). O działalności misyjnej tego apostoła na Wschodzie nie wspomina wprawdzie Nowy Testament, jednak opisy tego rodzaju znajdujemy już u wczesnych autorów i komentatorów chrześcijańskich, a zwłaszcza w apokryficznych Dziejach Tomasza (III w.). Zgodnie $\mathrm{z}$ tą tradycją św. Tomasz w trakcie pobytu w Indiach został zabity i tam go też pierwotnie pochowano ${ }^{46}$. Co istotne, w zakresie ewangelizacji Indii może on być traktowany jako prekursor dla zakrojonej na szeroką skalę działalności św.

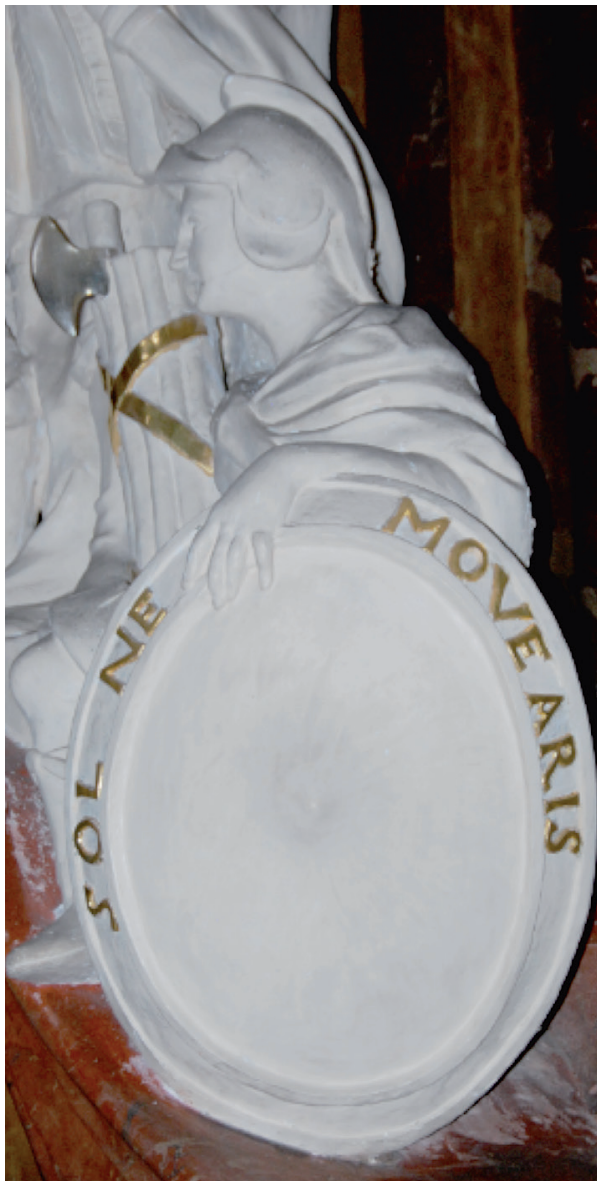

Fot. 20. Inskrypcja po prawej stronie ołtarza św. Franciszka Ksawerego
Franciszka Ksawerego, do którego dobrze pasuje umieszczony na inskrypcji passus z Brewiarza.

Grupa rzeźbiarska ustawiona po prawej stronie ołtarza to św. Jozue w rzymskiej zbroi wraz $\mathrm{z}$ giermkiem, który trzyma owalną tarczę ${ }^{47}$. $\mathrm{Na}$ obramowaniu tej tarczy biegnie łacińska inskrypcja:

\section{SOL NE MOVEARIS ${ }^{48}$ \\ „Słońce, nie ruszaj się!”}

Zdanie to pochodzi z Księgi Jozuego (10.12), opisującej podboje Kanaanu pod przywództwem Jozuego, następcy Mojżesza. Jedną z kolejnych walk po przekroczeniu Jordanu Jozue stoczył pod Gibeonem (ok. $10 \mathrm{~km}$ na północny zachód od Jerozolimy) ze sprzymierzonymi władcami Amorytów. Podczas bitwy nastąpił słynny „cud słońca”, który polegał na zatrzymaniu słońca na nieboskłonie aż do zwycięstwa Izraelitów. Odnośny passus $\mathrm{w}$ przekładzie Biblii Tysiąclecia brzmi następująco: „W dniu, w którym Pan podał Amorytów w moc Izraelitów, rzekł Jozue w obecności

${ }^{46}$ O św. Tomaszu Apostole vide Zaleski 1996: 366-368.

${ }^{47} \mathrm{O}$ interpretacji głównej figury jako Jozuego vide Kurzawa 1997: 277; Kurzawa - Kusztelski 1998: 20; Owczarzak 2009: 26. We wcześniejszych pracach traktuje się ten wizerunek jako Judę Machabeusza; tak podają Zwolski (1936: 25), Dubowski (1956: 203) i Szczepaniak (1996: 28).

${ }^{48}$ Litery wypukłe pomalowane złotą farbą na białym tle, majuskuła. Wydania: Zwolski 1936: 25; Szczepaniak 1996: 28; Kurzawa 1997: 277. 
Izraelitów: «Stań, słońce, nad Gibeonem! I ty, księżycu, nad doliną Ajjalonu!» I zatrzymało się słońce, i stanął księżyc, aż pomścił się lud nad wrogami swymi" (w. 12-13). Umieszczenie wizerunku św. Jozuego w kaplicy sugeruje paralelę pomiędzy chrystianizacją nowych terenów w Azji a wprowadzaniem Izraelitów i judaizmu do Kanaanu. Natomiast samo wyrażenie „Słońce, nie ruszaj się!” osadzone w kontekście św. Franciszka Ksawerego zdaje się wskazywać na niezwykłą czasochłonność działalności misyjnej ${ }^{49}$.

Dwie inne inskrypcje w tej kaplicy znajdują się na sklepieniu, gdzie na plafonie $\mathrm{z}$ malowidłem przedstawiającym chwałę św. Franciszka Ksawerego widnieje m.in. wizerunek dziecka w stroju orientalnym trzymającego otwartą księgę z ledwie widocznym napisem:

\author{
ECCE | DEDI | TE \\ IN | LUCEM | GENTIUM ${ }^{50}$ \\ „Oto uczyniłem cię światłem \\ dla narodów"
}

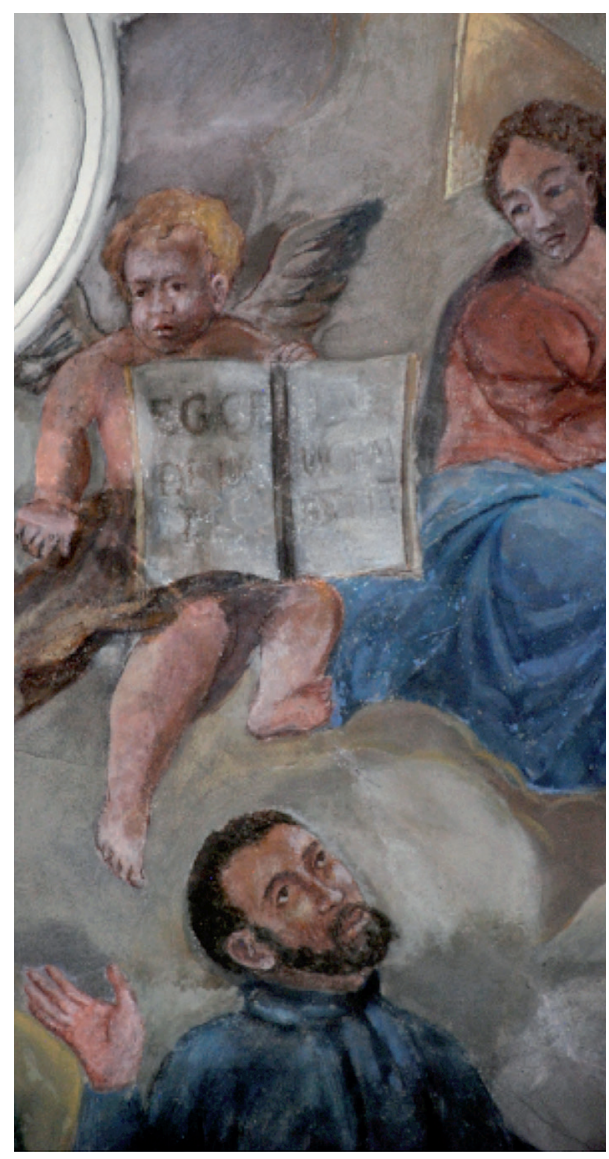

Fot. 21. Szczegół z malowidła na sklepieniu w kaplicy św. Franciszka Ksawerego

Cytat ten to część wersu z Księgi Izajasza (49.6). Jego dalszy ciąg w Wulgacie brzmi: „ut sis salus mea usque ad extremum terrae”, czyli „abyś był moim ocaleniem aż po krańce ziemi”. Ta dalsza część jest nader istotna w kontekście fary, ponieważ widnieje ona fragmentarycznie na tym samym malowidle poniżej. Przedstawiony w stroju egzotycznym czarnoskóry chłopiec trzyma sztandar, na którym możemy z trudem odczytać:

${ }^{49}$ Por. interpretację Kurzawy 1997: 277-278: „Jozue jest w tym wypadku prefigurą św. Franciszka Ksawerego, bo jak Jozue pierwszy przekroczył Jordan i wprowadził Izraelitów do Ziemi Obiecanej, tak św. Franciszek Ksawery przez chrzest wprowadzał pogan do Kościoła, dając im światło Wiary".

${ }^{50}$ Litery czarne na białym tle, majuskuła barokowa. Tekst w większości obecnie słabo czytelny. Wydania: Zwolski 1936: 25; Szczepaniak 1996: 28; Kurzawa 1997: 277. 


\section{[SA]LUS MEA | [USQU]E AD EXTREMUM ${ }^{51}$ „Moim ocaleniem aż po krańce" ${ }^{\text {„2 }}$}

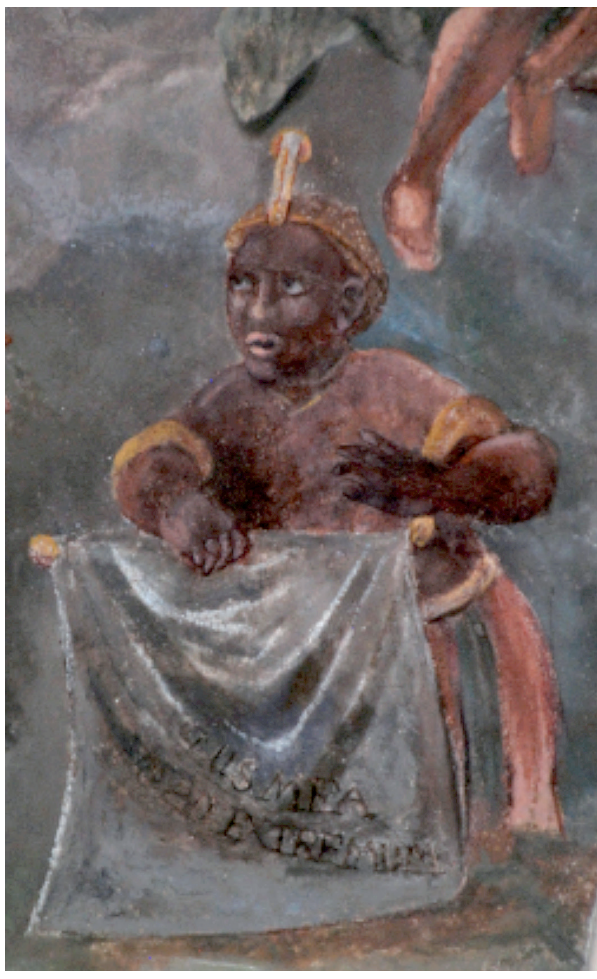

Fot. 22. Szczegół z malowidła na sklepieniu w kaplicy św. Franciszka Ksawerego
Mamy tutaj do czynienia $\mathrm{z}$ fragmentem wkomponowanej w Księgę Izajasza jednej z czterech Pieśni Sługi, w których ów Sługa interpretowany jest najczęściej jako naród Izraela lub Mesjasz. Wypada tu zaznaczyć, że cytat ten w Wulgacie ma nieco inny wydźwięk niż np. w Biblii Tysiąclecia, gdzie cały szósty wers brzmi w ten sposób: „A mówił (tj. Bóg): «To zbyt mało, iż jesteś Mi Sługą dla podźwignięcia pokoleń Jakuba i sprowadzenia ocalałych z Izraela! Ustanowię cię światłością dla pogan, aby moje zbawienie dotarło aż do krańców ziemi»»". W każdym razie wers ten można interpretować jako powołanie do działalności misyjnej i dlatego został on powiązany z postacią św. Franciszka Ksawerego.

Podsumowując, w pięciu kaplicach i dwóch ołtarzach dedykowanych świętym jezuickim znajduje się w sumie 21 inskrypcji, z których jedna nie jest dostępna, ponieważ znajduje się

z tyłu obrazu z przedstawieniem św. Franciszka Ksawerego i od początku nie była przeznaczona na widok publiczny. Możemy ponadto przypuszczać, że jeszcze jedna inskrypcja malowana widniała pierwotnie na księdze trzymanej przez putto w kaplicy św. Jana Franciszka Regisa (może z tekstem pauperibus panem - „ubogim chleba”?). Pod względem formy aż 11 spośród 20 widocznych inskrypcji zostało wpisanych w ozdobne kartusze. Kolejne 8 napisów zostało artystycznie wkomponowanych w rzeźby, malowidła ścienne i obraz w postaci ksiąg i zwojów. Jedna inskrypcja została umieszczona na wojskowej tarczy w grupie rzeźbiarskiej. Wszystkie te zabytki epigrafiki pełnią z jednej strony funkcje

\footnotetext{
${ }^{51}$ Litery czarne na (zabrudzonym) białym tle; majuskuła. Brak wydań. [USQU]E - litera $E$ jest w zasadzie nie do odczytania.

${ }^{52}$ Ten wyciągnięty z kontekstu fragment można przetłumaczyć także jako: „Moje ocalenie aż po krańce".
} 
ozdobników, z drugiej zaś - dostarczają danych pozwalających na identyfikację kaplic czy ołtarzy, a jednocześnie przekazują krótkie informacje nawiązujące do życia lub działalności poszczególnych świętych. Pod tym względem doskonale zagrano cytatami, które w nowym kontekście zyskują zupełnie inny sens.

Niektóre inskrypcje z upływem czasu uległy zniszczeniu i - w dwóch przypadkach - zostały błędnie odrestaurowane w toku prac konserwatorskich ${ }^{53}$. Dokładna analiza filologiczna i paleograficzna przeprowadzona w ramach niniejszego artykułu pozwala na zrekonstruowanie uszkodzonych tekstów. Przy ewentualnych kolejnych konserwacjach należałoby dokonać poprawek i uzupełnień inskrypcji namalowanych na zwojach w rzeźbach z kaplic św. Franciszka Borgiasza i św. Alojzego Gonzagi, a także napisów stanowiących część malowideł na sklepieniach kaplic św. Męczenników Jezuickich i św. Franciszka Ksawerego. Artykuł rzuca również nowe światło na treść inskrypcji znajdującej się na odwrocie głównego obrazu z kaplicy św. Franciszka Ksawerego i tym samym na historię tego obrazu.

\section{BIBLIOGRAFIA}

\section{Teksty źródłowe, przekłady}

Beatificatio et canonizatio ven. servi Dei Ioannis Francisci Regis Sacerdotis Professi Societatis Iesu, Roma 1710.

Breviarium Romanum ex Decreto Sacrosancti Concilii Tridentini restitutum, S. Pii V Pontificis Maximi iussu editum, et Clementis VIII primum, nunc denuo Urbani VIII auctoritate recognitum, Roma 1632.

Giordano Cascini, De vita et inventione S. Rosaliae, virginis Panormitanae commentarium breve, Panormum (= Palermo) 1631.

List ks. Antoniego Laubitza do ks. Antoniego Stychla z dnia 5 września 1913 r. - Archiwum Archidiecezjalne w Poznaniu, KF 774 (dokumenty niepaginowane).

Pismo Święte Starego i Nowego Testamentu, w przekładzie z języków oryginalnych, opracował zespół biblistów polskich z inicjatywy Benedyktynów Tynieckich, wyd. 3, poprawione, Poznań-Warszawa 1990 [tzw. Biblia Tysiąclecia, w skrócie: BT].

Quaedam ex constitutionibus cum regulis communibus Societatis excerpta, Roma 1560.

Sancti Ignatii de Loyola Constitutiones Societatis Jesu, t. I: Monumenta Consitutionum praevia, Roma 1934 (Monumenta Ignatiana ex autographis vel ex antiquioribus exemplis collecta, series tertia).

Sancti Ignatii de Loyola Constitutiones et Regulae Societatis Jesu, t. III: Regulae Societatis Iesu (1540-1556), ed. D.F. Zapico, Roma 1948 (Monumenta Ignatiana ex autographis vel ex antiquioribus exemplis collecta, series tertia).

\footnotetext{
${ }^{53} \mathrm{Nie}$ są to jedyne uszkodzone lub/i błędnie odrestaurowane inskrypcje w farze poznańskiej. Pod tym względem wymienić należy przede wszystkim dwa epitafia: ks. Kaspra Drużbickiego w kaplicy Matki Boskiej i ks. Józefa Pawłowskiego w kaplicy św. Krzyża; vide Rosół 2018: 194-201.
} 
Opracowania

Błaszczyk 2008: I. Błaszczyk, Konserwacja zabytków ruchomych w Poznaniu w latach 19902007, Poznań 2008.

Danielski 1976: W. Danielski, Brewiarz, w: Encyklopedia katolicka, red. F. Gryglewicz i in., t. II, Lublin 1976, kol. 1064-1071.

Dubowski 1956: A. Dubowski, Zabytkowe kościoły Wielkopolski, Poznań 1956.

Grzebień 2004: L. Grzebień (red.), Encyklopedia wiedzy o jezuitach na ziemiach Polski i Litwy. 1564-1995, wyd. 2, Kraków 2004.

Kurzawa 1997: Z. Kurzawa, Ottarz św. Franciszka Ksawerego w kościele pojezuickim w Poznaniu, Kronika Miasta Poznania 4 (1997), 276-283.

Kurzawa - Kusztelski 1998: Z. Kurzawa, A. Kusztelski (red.), Katalog zabytków sztuki. Miasto Poznań, cz. II. Śródmieście. Kościoły i klasztory 1, Warszawa 1998.

Lewandowski 2009: M. Lewandowski (autor podpisów zdjęć) w: P. Skórnicki (fot.), Fara Church. Pfarrkirche. Fara, Poznań 2009.

Owczarzak 2009: P. Owczarzak, Pierwsza parafia miasta. Przewodnik po farze poznańskiej, Poznań 2009.

Rosół 2018: R. Rosół, Łacińskie epitafia w farze poznańskiej, „Symbolae Philologorum Posnaniensium" 1 (2018), 187-203.

Szczepaniak 1996: M. Szczepaniak, Fara poznańska. Przewodnik, wyd. 2, popr., Poznań 1996.

Wielkopolski Urząd Wojewódzki w Poznaniu: http://www.poznan.uw.gov.pl.

Zwolski 1936: S. Zwolski, Przewodnik po farze poznańskiej, Poznań 1936.

Zaleski 1996: W. Zaleski, Święci na każdy dzień, wyd. uzupełnione, Warszawa 1996.

\section{LATIN EPIGRAPHY IN THE PARISH CHURCH IN POZNAŃ. INSCRIPTIONS IN THE ALTARS AND CHAPELS OF THE JESUIT SAINTS}

\section{Sum mary}

The former Jesuit Church in Poznan (now the Parish Church) delivers almost 200 Latin inscriptions of different kinds. The goal of this paper is to present the epigraphic evidence from the altars and chapels of Jesuit Saints, i.e. Saint Stanislaus Kostka, Saint Ignatius of Loyola, Saint Francis Borgia, Saint Aloysius de Gonzaga, Saint John Francis Regis, the Saint Jesuit Martyrs and Saint Francis Xavier. In sum, there are 21 inscriptions. One of them is not available, because it is written on the back side of a painting (we have at our disposal its content from an archive document). Perhaps, one more inscription existed earlier in the chapel of Saint John Francis Regis, but now it is invisible. The paper provides a critical edition of the inscriptions, their Polish translations, as well as a philological, palaeographical and historical commentary. 